\title{
Electrochemical Removal of Hexavalent Chromium Using Electrically Conducting Carbon Nanotube/Polymer Composite Ultrafiltration Membranes
}

\author{
Wenyan Duan ${ }^{\dagger}$, Gongde Chen $^{\dagger}$, Chuxiao Chen ${ }^{\dagger}$, Riya Sanghvi ${ }^{\dagger}$, Arpita Iddya ${ }^{\dagger}$, Sharon Walker ${ }^{\dagger}$, \\ Haizhou Liu ${ }^{\dagger}$, Avner Ronen ${ }^{\psi}$ and David Jassby* ${ }^{\dagger}$ \\ ${ }^{\mp}$ Department of Chemical and Environmental Engineering, University of California, Riverside, USA \\ ${ }^{\psi}$ Department of Chemical and Environmental Engineering, College of Engineering, Temple University, \\ USA \\ $\Psi$ Correspondence to: Temple University, Philadelphia, PA 19122, USA \\ Tel.: (909)328-9282 \\ Email: avner.ronen@temple.edu \\ * Correspondence to: University of California, Riverside, Riverside, CA 92521, USA. \\ Tel.: (951)-827-6475. \\ E-mail: djassby@engr.ucr.edu
}

\begin{abstract}
Hexavalent chromium $(\mathrm{Cr}(\mathrm{VI}))$ contamination in drinking water resources remains a challenge in many parts of the United States, as well as in regions affected by industrial pollution. In this study, we demonstrated how electrically conducting carbon nanotube (CNT) - polyvinyl alcohol (PVA) composite ultrafiltration (UF) membranes can be used to remove $\mathrm{Cr}$ (VI) from water through a combined process of electrostatic repulsion, electrochemical reduction, and precipitation. The impact of different operational (flux, contact time, applied electrical potential) and environmental ( $\mathrm{pH}$ and salinity) conditions on $\mathrm{Cr}(\mathrm{VI})$ removal were evaluated. Due to the native electrical potential of the CNT/PVA UF membrane material, approximately $45 \%$ removal of $1 \mathrm{ppm} \mathrm{Cr}(\mathrm{VI})$ solution was detected under neutral $\mathrm{pH}$ conditions in deionized water. Increased $\mathrm{Cr}(\mathrm{VI})$ removal was observed with increasing membrane surface charge density, which was accomplished through the application of an external potential $(3 \mathrm{~V}, 5 \mathrm{~V}$ and $7 \mathrm{~V}$, membrane as cathode) to the electrically conductive membrane surface. The solution ionic strength showed a significant impact on $\mathrm{Cr}(\mathrm{VI})$ removal. By increasing the ionic strength without applying external potential on the membrane, the electrostatic repulsive force between the charged membrane surface and the $\mathrm{CrO}_{4}{ }^{2-}$ ion was eliminated, and $\mathrm{Cr}(\mathrm{VI})$ removal dropped to zero. The highest removal (95\%) was achieved when $7 \mathrm{~V}$ was applied to the membrane/counter electrode with a 6 $\mu$ m-thick membrane. Here, $\mathrm{Cr}(\mathrm{VI})$ was electrochemically reduced to $\mathrm{Cr}$ (III) on the membrane surface, followed by $\mathrm{Cr}(\mathrm{III})$ precipitation as chromium hydroxide $\mathrm{Cr}(\mathrm{OH})_{3(\mathrm{~s})}$, which occurred by $\mathrm{Cr}$ (III) reacting with hydroxide ions generated via water splitting on the CNT network. Precipitated $\mathrm{Cr}(\mathrm{OH})_{3}$ was then removed by the UF membrane. In addition, CNT-PVA UF membranes were used to treat tap water spiked with $\mathrm{Cr}(\mathrm{VI})$; under these conditions, $99 \% \mathrm{Cr}(\mathrm{VI})$ removal was observed when $7 \mathrm{~V}$ were applied to the membrane/counter electrode. Furthermore, we demonstrate that other trace inorganic contaminants, such as uranium, were effectively removed as well.
\end{abstract}

Keywords: CNTs, chromate, ultrafiltration membranes, electro-reduction, electrostatic repulsion 


\section{Introduction}

Chromium is a common element that is both naturally ubiquitous and widely used in a variety of industrial applications, such as electroplating, textile processing, oil refining, corrosion protection, and pigment manufacturing [1]. A combination of poor wastewater management practices and natural geological formations have led to its wide occurrence in many communities' drinking water resources [2-6]. In the environment, chromium is generally found in one of two stable redox states: hexavalent chromium $(\mathrm{Cr}(\mathrm{VI}))$ and trivalent chromium $(\mathrm{Cr}(\mathrm{III}))$ [7,8]. $\mathrm{Cr}(\mathrm{VI})$ is highly soluble and mobile at neutral $\mathrm{pH}$, and $\mathrm{Cr}$ (III) is considered a trace elements needed in the human diet [7]. The redox state and speciation of chromium depends on water chemistry, including the $\mathrm{pH}$, and chromium concentration [9]. Due to the high toxicity of $\mathrm{Cr}$ (VI), the US EPA set the maximum concentration level (MCL) for total chromium in drinking water at 100 ppb [10]. The state of California set the MCL for $\mathrm{Cr}(\mathrm{VI})$ (the toxic form,) at $10 \mathrm{ppb}$ [11]; the US EPA does not currently have a specific MCL for $\mathrm{Cr}(\mathrm{VI})$. However, a recent study reported that the safe drinking water concentration of $\mathrm{Cr}(\mathrm{VI})$ may be as low as $0.02 \mathrm{ppb}$, which means that approximately $75 \%$ of American households may be a exposed to harmful $\mathrm{Cr}(\mathrm{VI})$ concentrations in their water [11-13].

Several technologies have been developed to remove $\mathrm{Cr}(\mathrm{VI})$ from water. Conventional $\mathrm{Cr}(\mathrm{VI})$ treatment technologies include physical adsorption [14,15], ion exchange [16-18], nanofiltration (NF) and reverse osmosis (RO) [19-21], chemical reduction followed by precipitation [22], photo-catalytic reduction [23,24], bio-mitigation [22] and electrochemical reduction $[22,25,26]$. The most commonly used technology in industry to treat $\mathrm{Cr}(\mathrm{VI})$ is chemical reduction (e.g. using ferrous iron) followed by precipitation [4,22]. Unfortunately, this process produces large volumes of waste sludge that requires expensive disposal [27,28]. Ion exchange, NF, and RO have shown great potential to efficiently remove different heavy metals [20,29], but they all result in the production of toxic brine and are expensive to operate [30]. Ultrafiltration (UF) membranes are widely used in water treatment processes due to their low pressure demands and wide range of chemical stability [31]. Several studies have demonstrated the use of UF membrane for $\mathrm{Cr}(\mathrm{VI})$ removal, however, $\mathrm{Cr}(\mathrm{VI})$ removal for typical polysulfone $(10 \mathrm{~K} \mathrm{Da}) \mathrm{UF}$ membranes is very limited, with the maximum rejection of 20\% [32-34]. Typical approaches attempted to increase $\mathrm{Cr}(\mathrm{VI})$ rejection by UF membranes include reducing the UF membrane's pore size [32] and increasing the membrane surface charge [33,34]. To the best of our knowledge, very few UF membrane has been demonstrated to efficiently and reliably reduce $\mathrm{Cr}(\mathrm{VI})$ concentrations to acceptable limits.

Electrochemical reduction is a process that relies on the transfer of electrons from a charged cathode to the $\mathrm{Cr}(\mathrm{VI})$ species, which reduces the $\mathrm{Cr}(\mathrm{VI})$ to $\mathrm{Cr}(\mathrm{III})$ and can lead to the formation of a solid precipitate [35]. $\mathrm{Cr}(\mathrm{VI})$ speciation at environmentally-relevant concentrations is $\mathrm{pH}$ dependent, with $\mathrm{HCrO}_{4}^{-}$being the dominant species at $\mathrm{pH}<6.45$, and $\mathrm{CrO}_{4}{ }^{2-}$ the dominant species at $\mathrm{pH}>6.45$ [9]. This process has been considered an environmentally "clean" technology for $\mathrm{Cr}(\mathrm{VI})$ treatment [36], because the precipitate it produces is pure $\mathrm{Cr}(\mathrm{OH})_{3(\mathrm{~s})}$ [27]. Electrochemical reduction processes are highly dependent on the $\mathrm{pH}$, electrolyte species, electrode material, and mass transfer rates [4,25,27,37]. Typical electrodes used for the electrochemical reduction of $\mathrm{Cr}(\mathrm{VI})$ are made of metals [38] or carbon $[32,39,40]$. As carbon electrodes are cheap and can be fabricated into structures with high surface-area-to-volume ratios, many groups have adopted their use. However, electrochemical treatment of $\mathrm{Cr}(\mathrm{VI})$ is typically conducted in a mass-transport limited batch process that requires long contact times, making the process difficult to scale up [26]. To reduce these mass transfer 
limitations, flow-through electrochemical processes (also known as electrochemical filtration), where the contaminated water is forced through a porous electrode, have been demonstrated for a wide range of electrochemical redox processes [41,42].

Electrically conducting carbon nanotube (CNT)/polymer composite and other conductive membranes have been demonstrated to be effective at multiple membrane separation processes, including UF, NF, and RO [43-51]. In these membranes, the CNT provides the electrical conductivity, while a crosslinking polymer (e.g. polyaniline (PANI) or polyvinyl alcohol (PVA)) is used to control the pore-size between the CNT strands [41]. These membranes have been demonstrated to be capable of supporting electrochemical reactions, such as water splitting, oxygen reduction, and chloride oxidation [41,47,48,52,53]. In this work, we used CNT/PVA composite UF membranes to electrochemically and reductively remove $\mathrm{Cr}(\mathrm{VI})$ from contaminated water, with removal efficiencies exceeding $95 \%$. We demonstrate that the removal mechanism is highly dependent on solution conductivity, with higher solution conductivity leading to electrochemical reduction and precipitation of $\mathrm{Cr}$ (III) on the membrane surface, while very low conductivity leads to electrostatic repulsion being responsible for $\mathrm{Cr}(\mathrm{VI})$ rejection from the permeate. In addition, we evaluated the impact of electrical potential and membrane residence time on $\mathrm{Cr}(\mathrm{VI})$ removal and transformation, and characterized the precipitates that form on the membrane surface in response to the potential application. Finally, we evaluated the membrane performance while treating tap water spiked with $\mathrm{Cr}(\mathrm{VI})$. Under these realistic conditions, less than $20 \mathrm{ppb}$ chromium was able to detected in the UF permeate, and we determined that the membrane was capable of removing other hazardous metal anions, such as uranium.

\section{Materials and Methods}

\subsection{Chemical and Materials}

PS-35 polysulfone UF membranes were purchased from Nanostone (Nanostone Inc., Oceanside, CA). Multi-walled carboxylic group functionalized CNTs were purchased from CheapTubes (Cheaptubes Inc., Brattleboro, VT), with the reported parameters: outer diameter of 13-18 nm, length of 3-30 $\mu \mathrm{m}$, and functional group content $\geq 7.0 \mathrm{w} / \mathrm{w} \%$. Analytic grade dodecylbenzenesulfonic acid (DDBS), sodium sulfate $\left(\mathrm{Na}_{2} \mathrm{SO}_{4}\right)$, potassium dichromate $\left(\mathrm{K}_{2} \mathrm{Cr}_{2} \mathrm{O}_{7}\right)$ glutaraldehyde, hydrochloric acid and $150 \mathrm{kDa}$ PVA were purchased from Fisher Scientific (Pittsburg, PA), and used as received. Deionized water $\left(18 \mathrm{~m} \Omega \mathrm{cm}^{-1}\right)$ was obtained from a Millipore Milli-Q system. Grade 2 titanium sheet (1/8" thick) was used as a counter electrode (McMaster, Santa Fe Springs, CA).

\subsection{PVA-CNT Membrane Fabrication}

The PVA-CNT membrane fabrication method has been previously developed by Dudchenko et al.[43]. In short, 0.01 wt. \% CNT powder and 0.1 wt. \% DDBS in DI water were well-suspended using a horn sonicator. 1 wt. $\%$ of $150 \mathrm{kDa}$ PVA was dissolved in DI water. 1: 3 ratio of PVA:CNT solution was pressure deposited onto a PS-35 UF membrane support and cross-linked in glutaraldehyde and hydrochloric acid solution for 1 hour at $90{ }^{\circ} \mathrm{C}$, then dried at same temperature for $5 \mathrm{~min}$ and stored at room temperature. 


\subsection{Membrane Characterization}

The Membrane's surface morphology and cross-section were imaged by scanning electron microscopy (SEM, FEI XL 30 SEM-FEG, Hillsboro, RO). New membrane samples were sputter-coated with a $\mathrm{Pt} / \mathrm{Pb}$ target for 40 s (Sputter coater 108 Auto, Cressington, UK) and examined at $10 \mathrm{keV}$ using SEM. For cross-sectional images, membranes were frozen in liquid nitrogen and fractured, then affixed onto SEM stubs with copper tape. Post-experiment membrane samples were gently washed with DI water, dried at room temperature and examined using SEM without any additional coating and by energy dispersive X-ray spectrometer (EDS). X-ray photoelectron spectroscopy (XPS) provided information on elemental composition and oxidation state of all the compounds. A Kratos AXIS ULTRA ${ }^{\text {DLD }}$ XPS system equipped with an $\mathrm{Al} \mathrm{K} \alpha$ monochromated $\mathrm{X}$-ray source and a $165-\mathrm{mm}$ mean radius electron energy hemispherical analyzer was used to acquire the data. The conditions for $\mathrm{Cr}$ analysis were $0.1 \mathrm{eV}$ step, $200 \mathrm{~ms}$ of dwell time and $20 \mathrm{eV}$ of pass energy. Vacuum pressure was kept below $3 \times 10^{-9}$ torr during the acquisition. Zeta potentials of suspended surfactant-free CNTs were measured in both $\mathrm{pH}$ and ionic strength controlled solutions using a ZetaPals instrument (Brookhaven Instruments Corp., Holtsville, NY).

\subsection{Synthetic Cr(VI) Solution}

$1 \mathrm{~g} / \mathrm{L} \mathrm{Cr}(\mathrm{VI})$ stock solutions were prepared by dissolving $5.65 \mathrm{~g}$ potassium dichromate $\left(\mathrm{K}_{2} \mathrm{Cr}_{2} \mathrm{O}_{7}\right)$ in $\mathrm{DI}$ water without $\mathrm{pH}$ adjustment. The experimental solutions were diluted to $1 \mathrm{ppm}$ from the stock solution using DI water, except in tap water experiments, which used City of Riverside tap water for dilution. $\mathrm{Na}_{2} \mathrm{SO}_{4}$ salt was used to adjust the ionic strength (background electrolyte) of the $\mathrm{Cr}(\mathrm{VI})$ because of its relative electrochemical stability [54].

\subsection{Electrochemical Characterization}

The relative potential of the membrane vs. a $\mathrm{Ag} / \mathrm{AgCl}$ reference electrode, as a function of the applied cell potential, was determined by placing the membrane (working electrode), a pristine titanium sheet (unless has been noted) as counter electrode and a reference electrode into an electrochemical cell containing DI water and a supporting electrolyte $\left(\mathrm{Na}_{2} \mathrm{SO}_{4}\right)$. The cell potential was applied to the membrane and titanium counter electrode using a DC power source, and the relative potential on the membrane was determined by connecting the membrane, counter electrode and reference electrode to a potentiostat (CH Instruments, Austin, TX), which measured the open-circuit potential on the membrane (working electrode). The electrochemical behavior of cathodic $\mathrm{Cr}(\mathrm{VI})$ reduction was investigated by background-subtracted cyclic voltammetry $(\mathrm{CV})$. The tests were performed using a three-electrode cell connected to an electrochemical workstation (WaveDriver 20, Durham, NC). The system used a PVA-CNT membrane coupon $\left(4 \mathrm{~cm}^{2}\right)$ as the working electrode, platinum foil as counter electrode, and a $\mathrm{Ag} / \mathrm{AgCl}$ electrode as the reference electrode. Measurements were performed using a $60 \mathrm{mM}$ $\mathrm{Cr}(\mathrm{VI})$ solution at pHs of 4,7 and 10 with $0.5 \mathrm{M} \mathrm{Na}_{2} \mathrm{SO}_{4}$ as the supporting electrolyte. $1 \mathrm{mM}$ phosphate buffer was added to the background electrolyte solution to control $\mathrm{pH}$ changes at $\mathrm{pH} 7$. All solutions were purged with nitrogen for 30 minutes prior to use. Background CV experiments were conducted under identical conditions, except that $\mathrm{Cr}(\mathrm{VI})$ was omitted. The background $\mathrm{CV}$ curves were subtracted from the $\mathrm{CV}$ curves generated in the presence of $\mathrm{Cr}(\mathrm{VI})$. In all $\mathrm{CV}$ experiments, the scan rate was held at $10 \mathrm{mV} / \mathrm{s}$ with the voltage ranging between 1 and $-1.5 \mathrm{~V}$. Membrane capacitance was determined using an electrochemical station (CH Instruments, Austin, TX). 


\subsection{Experimental Details}

Membrane experiments were carried out using a custom built, cross-flow filtration unit (Figure S1) [55]. This filtration cell has an active filtration surface of $40 \mathrm{~cm}^{2}(10 \mathrm{~cm} \times 4 \mathrm{~cm})$ with a titanium sheet serving as a counter electrode located $3 \mathrm{~mm}$ above the membrane surface, as shown in Figure S1. In all experiments, the titanium counter electrode had already been exposed to $7 \mathrm{~V}$ cell potential, which led to its pre-oxidation. The crossflow velocity was set at 9 $\mathrm{cm} / \mathrm{s}$ and permeate flux maintained at $8\left(\mathrm{Liter} / \mathrm{m}^{2} / \mathrm{hour}\right.$, LMH). Three different sets of experiments were conducted to demonstrate $\mathrm{Cr}(\mathrm{VI})$ removal efficiency of low pressure electrically conductive UF membranes under $0,10100 \mathrm{mM} \mathrm{Na}_{2} \mathrm{SO}_{4}$ solution and 3, 5, 7V cell potentials, with the membrane always functioning as the cathode. Each experiment lasted six hours; during the first three hours, no potential was applied to the membrane surface and the baseline $\mathrm{Cr}(\mathrm{VI})$ removal of the membrane was determined. In the first set of experiments, after the first three hours, $3 \mathrm{~V}, 5 \mathrm{~V}$ or $7 \mathrm{~V}$ were applied to the membrane/counter electrode in $\mathrm{Cr}(\mathrm{VI})$ spiked DI water. In the second set of experiments, after the first three hours, $5 \mathrm{~V}$ and $7 \mathrm{~V}$ were applied to membrane/counter electrode under varying $\mathrm{Na}_{2} \mathrm{SO}_{4}$ concentrations and membrane thickness' ( $2 \mu \mathrm{m}$ and $6 \mu \mathrm{m})$, corresponding to a membrane residence time of $0.9 \mathrm{~s}$ and $2.7 \mathrm{~s}$ for the $2 \mu \mathrm{m}$ and $6 \mu \mathrm{m}$ membrane thickness, respectively. In the third set of experiments, after the first three hours, $7 \mathrm{~V}$ was applied to the membrane/counter electrode to treat tap water spiked with $\mathrm{Cr}(\mathrm{VI})$. All experiments were at least duplicated. Membrane removal (R) was calculated based on the $\mathrm{Cr}(\mathrm{VI})$ concentration in the feed $\left(\mathrm{C}_{\mathrm{F}}\right)$ and permeate $\left(\mathrm{C}_{\mathrm{P}}\right)$ stream:

$$
\mathrm{R}(\%)=\left(1-\frac{C_{P}}{C_{F}}\right) \times 100 \%
$$

Membrane residence time (t) was calculated based on membrane thickness $(\zeta, \mu \mathrm{m})$ and permeate flux $(v, \mu \mathrm{m} / \mathrm{s})$ :

$$
\mathrm{t}(\mathrm{s})=\frac{\zeta}{v}
$$

The capacitance of the CNT-UF membrane was calculated using the following equation[56]:

$$
\mathrm{C}=\frac{\oint_{E 1}^{E 2} i(E) d E}{2 \Delta V v A}
$$

where $\mathrm{C}$ is the capacitance of a membrane unit area $\left(\mathrm{C} / \mathrm{cm}^{2}\right), \mathrm{E} 1$ and $\mathrm{E} 2$ are the cutoff potentials in used during $\mathrm{CV}, \mathrm{i}(\mathrm{E})$ is the instantaneous current, $\oint_{E 1}^{E 2} i(E) d E$ is the total voltammetric charge obtained by integration of the positive and negative $\mathrm{CV}$ scan, $\Delta V$ is the potential window in the $\mathrm{CV}$ scan, $v(\mathrm{~V} / \mathrm{s})$ is the $\mathrm{CV}$ scan rate, and $\mathrm{A}$ is the membrane area.

The following equation was derived from the Extended Nernst plank equation and was used to simulate the CNT-UF membrane rejection in DI water (See SI for details)[57].

$$
\frac{d c_{i}}{d x}=\frac{c_{i}-C_{i, P}}{u_{i}^{o} R T} j_{v}-\frac{z_{i} c_{i} F}{R T} \cdot \frac{d \varphi}{d x}
$$

where $c_{i}\left(\mathrm{~mol} \cdot \mathrm{m}^{-3}\right)$ is the concentration of the $i$-th ion inside the membrane. $C_{i, P}\left(\mathrm{~mol} \cdot \mathrm{m}^{-3}\right)$ is the $i$-th ion in the permeate stream. $u_{i}^{o}\left(\mathrm{~mol} \cdot \mathrm{m}^{2} \cdot J^{-1} \cdot \mathrm{s}^{-1}\right)$ is the ionic mobility of $i$-th ion $\left(5.58 \times 10^{-13}\right.$ for $\mathrm{CrO}_{4}{ }^{2-}$ and for $\left.5.38 \times 10^{-13} \mathrm{Na}^{+}\right)[57,58] . \mathrm{R}\left(\mathrm{J} \cdot \mathrm{mol}^{-1} \cdot K^{-1}\right)$ is gas constant (8.3145). $z_{i}$ is the valance of $i$-th ion species. $\mathrm{F}\left(\mathrm{C} \cdot \mathrm{mol}^{-1}\right)$ is faraday constant $(96485.33) . \varphi(x)$ $(\mathrm{V})$ is the potential as the function of distance inside the membrane. $j_{v}\left(\mathrm{~m}^{3} \cdot \mathrm{m}^{-2} \cdot \mathrm{s}^{-1}\right)$ is the is the volume flux based on membrane pore area. 


\subsection{Cr (VI), Cr (III), and other metal measurement methods}

$\mathrm{Cr}(\mathrm{VI})$ concentrations were measured using a colorimetric method, which involved the addition of diphenylcarbazide followed by measuring light absorption at $540 \mathrm{~nm}$ using a Hach DR 800 spectrophotometer [59]. Total chromium and other metal concentrations were measured using inductively coupled plasma mass spectrometry (ICP-MS, 7700 Series, Agilent Technologies, Santa Clara, CA), after samples were treated with $2 \%$ nitric acid. Cr(III) concentrations were calculated by subtracting $\mathrm{Cr}(\mathrm{VI})$ concentrations from the total chromium concentration.

\section{Results and Discussions}

\subsection{Surface Characterization and Physical Properties of PVA-CNT UF Membranes}

SEM images of the PVA-CNT membrane surface and cross-section are shown in Figures 1A-C. Depending on the volume of the CNT solution used in the pressure deposition process, various membrane thicknesses can be achieved. In the present work, two different thicknesses of PVA-CNT membranes were fabricated: depositing $150 \mathrm{ml}$ of CNT solution resulted in a CNT layer thickness of $2 \mu \mathrm{m}$, and $450 \mathrm{ml}$ of CNT solution resulted in a $6 \mu \mathrm{m} \mathrm{CNT} \mathrm{layer.} \mathrm{The} \mathrm{cross-}$ sectional images confirmed that the thickness of the PVA-CNT membranes can be well controlled by the volume of CNT solution deposited on the support [60]. Due to the presence of the CNTs, these membranes have an unusual black color (Figure $1 \mathrm{D}$ ). The pore size through a CNT network deposited on a porous polymeric support was determined to be $125 \mathrm{~nm}$, which is far larger than the pores of the polymeric support (with a molecular weight cutoff of $100 \mathrm{kDa}$ ) [41]. Thus, the MWCO of the composite structure is dominated by the underlying polymeric support.

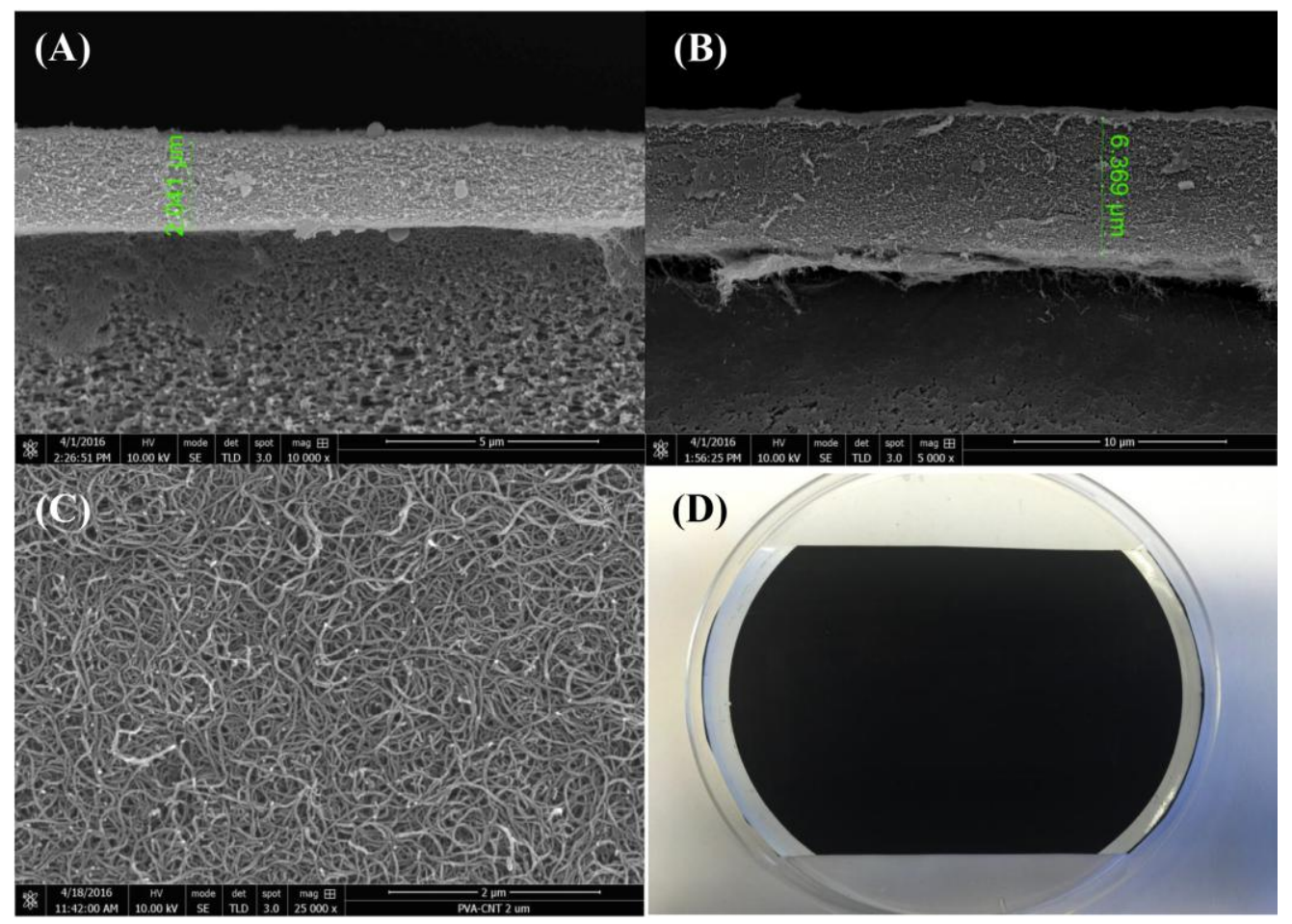


Figure 1: PVA-CNT membranes surface and cross-section. (A) Cross-section of $2 \mu \mathrm{m}$-thick membrane. (B) Cross-section of $6 \mu \mathrm{m}$-thick membrane (C) the surface morphology of PVA-CNT membrane at a magnification of 25,000 X clearly showing individual, non-aggregated CNTs. (D) Photo of a PVA-CNT membrane surface.

The surface charge of the CNTs used to fabricate the PVA-CNT UF membranes was evaluated under different ionic strengths and $\mathrm{pH}$ levels (Figure S2). In DI water, the CNTs were negatively charged $(-49 \mathrm{mV})$ at $\mathrm{pH} 10$, while at $\mathrm{pH} 4$, the zeta potential was $-21.1 \mathrm{mV}$. Under high ionic strength conditions $\left(100 \mathrm{mM} \mathrm{Na}_{2} \mathrm{SO}_{4}\right)$, the CNT zeta potential ranged between -10 and $-20 \mathrm{mV}$ across all $\mathrm{pH}$ ranges tested (4 -10). Under moderate ionic strength $\left(10 \mathrm{mM} \mathrm{Na}_{2} \mathrm{SO}_{4}\right)$, the zeta potential was from -10 to $-44 \mathrm{mV}$. The intrinsic negative charge of the CNT-based membrane results from the protonation/deprotonation of the carboxylic acid groups on the CNT surface [15]. The capacitance of the membrane as a function of membrane thickness was determined to be $0.001 \pm 0.001,0.013 \pm 0.0001$, and $0.043 \pm 0.005 \mathrm{~F} / \mathrm{cm}^{2}$ for a $1 \mu \mathrm{m}, 2 \mu \mathrm{m}$, and 6 $\mu$ m-thick membrane, respectively (Figure S3). Thus, there was a linear relationship between CNT thickness and capacitance, with an $\mathrm{R}^{2}$ value of 0.96 (Figure S3).

\subsection{Electrochemical Characterization and Reduction of $\mathrm{Cr}(\mathrm{VI})$}

The application of a cell potential had an immediate and dramatic impact on the relative potential of the membrane (vs. a $\mathrm{Ag} / \mathrm{AgCl}$ reference). Figure 2 describes the relative potential of the membrane as a function of time under different electrolyte concentrations, membrane thicknesses, and cell potentials. Upon the application of the potential, there is a dramatic decrease in the cathodic potential of the membrane. However, the potential rapidly increases (becoming less negative), reaching a stable value after approximately 1000 seconds (Figure 2). This phenomenon is observed under all electrolyte concentrations (DI water, 10 and $100 \mathrm{mM}$ $\mathrm{Na}_{2} \mathrm{SO}_{4}$, tap water) and all cell potentials $(3,5$, and $7 \mathrm{~V}$ ). The final (stable) relative potentials of the membrane are summarized in Figure 3. Visual inspection of the titanium counter electrode reveals the formation of a yellowish layer (Figure 2). Taken together, these results are indicative of corrosion on the titanium counter electrode, which is exposed to anodic (oxidizing) currents [61]. The corrosion of the titanium counter electrode leads to the formation of a metal oxide layer, which increases the overall resistance of the electrochemical system. Thus, there is a large voltage drop between the titanium anode and the membrane cathode, which leads to the relatively low relative potentials measured on the membrane surface. 

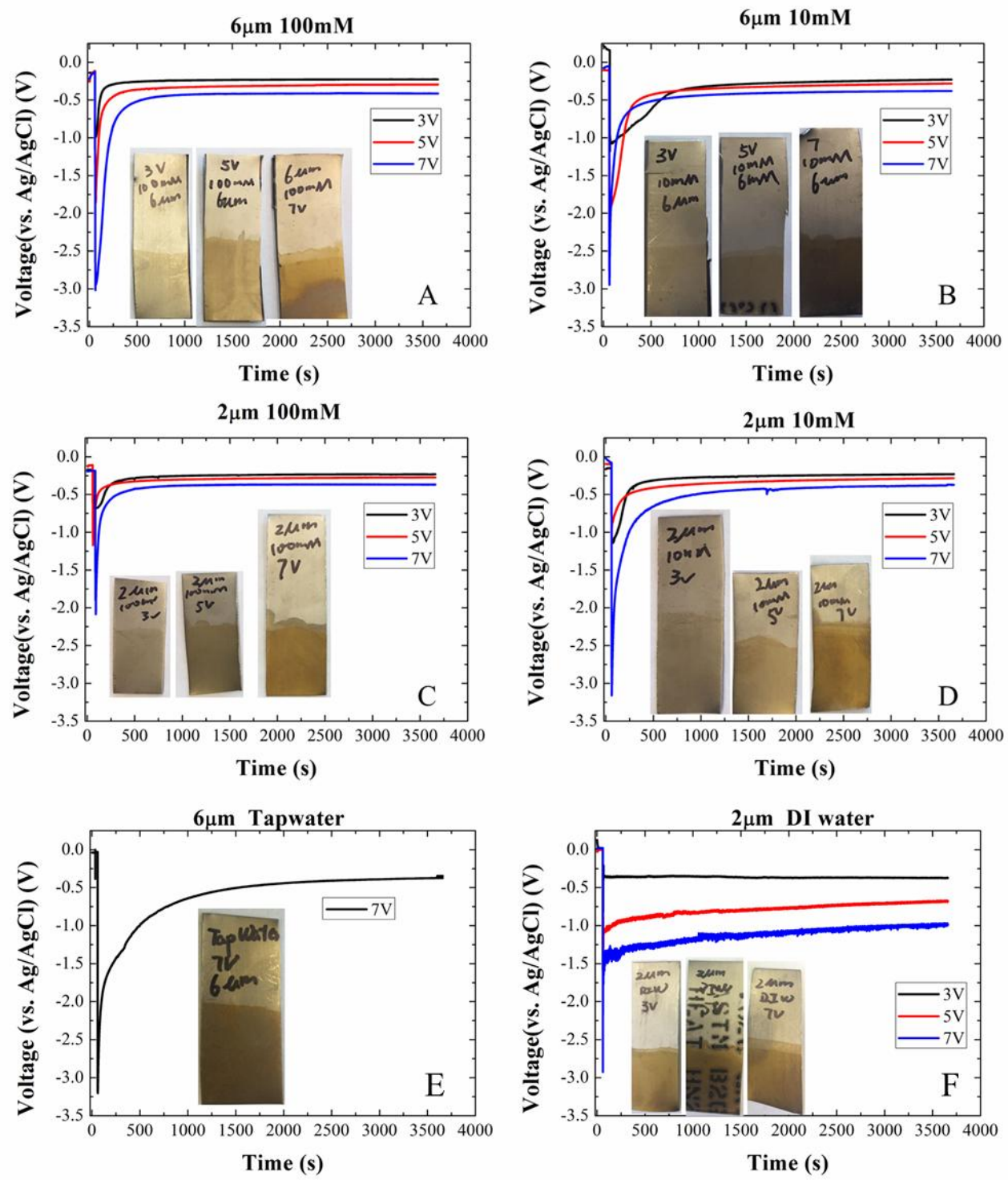

Figure 2. Membrane cathodic potentials (vs. $\mathrm{Ag} / \mathrm{AgCl}$ ) over time when 3,5 , and $7 \mathrm{~V}$ cell potentials were applied. Inset figures are the images of Ti electrode taken after the experiments showing the pristine $\mathrm{Ti}$ that was not immersed and the darker, immersed region that experienced oxidation. (A) $6 \mu$ m-thick membrane, $100 \mathrm{mM} \mathrm{Na}_{2} \mathrm{SO}_{4}$ solution; (B) $6 \mu \mathrm{m}$-thick membrane, $10 \mathrm{mM} \mathrm{Na}_{2} \mathrm{SO}_{4}$ solution; (C) $2 \mu \mathrm{m}$-thick membrane, $100 \mathrm{mM} \mathrm{Na}_{2} \mathrm{SO}_{4}$ solution; (D) $2 \mu$ m-thick membrane, $10 \mathrm{mM} \mathrm{Na}_{2} \mathrm{SO}_{4}$ solution; (E) $6 \mu \mathrm{m}$-thick membrane, tap water; (E) $2 \mu \mathrm{m}$-thick membrane, DI water, pre-oxidized Ti electrode. 


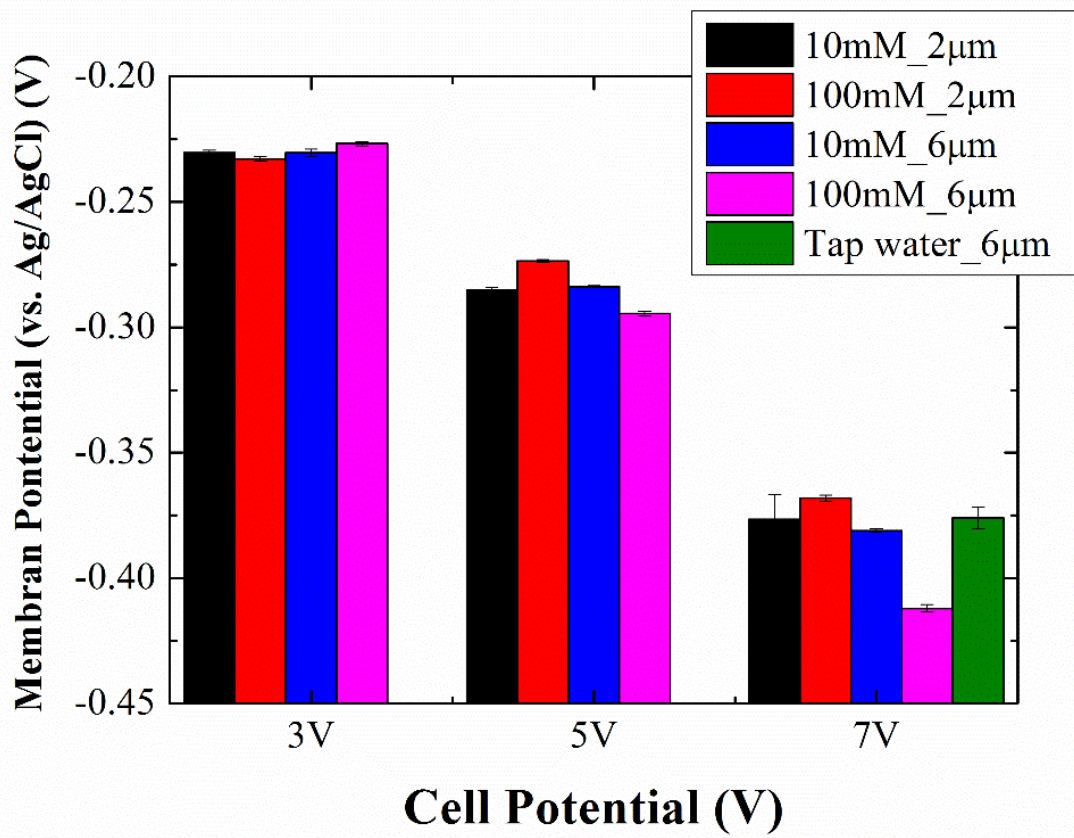

Figure 3. Stable cathodic potential (vs. $\mathrm{Ag} / \mathrm{AgCl}$ ) on the membrane surface, when 3,5 and $7 \mathrm{~V}$ cell potentials were applied in 10, $100 \mathrm{mM} \mathrm{Na}_{2} \mathrm{SO}_{4}$ solutions and tap water for both 2 and $6 \mu \mathrm{m}$ thick membranes.

$\mathrm{CV}$ was used to study the electrochemical reactions when an electrically charged PVACNT membrane was placed in contact with a solution of $\mathrm{Cr}(\mathrm{VI})\left(60 \mathrm{mM} \mathrm{K}_{2} \mathrm{Cr}_{2} \mathrm{O}_{7}\right)$ at different $\mathrm{pH}$ values in the presence of $0.5 \mathrm{M} \mathrm{Na}_{2} \mathrm{SO}_{4}$ as a supporting electrolyte. When chromium was present in the solution, a clear reduction peak is evident, with a reduction potential of $-0.31 \mathrm{~V}$, $0.37 \mathrm{~V}$, and $-0.37 \mathrm{~V}$ (vs. $\mathrm{Ag} / \mathrm{AgCl}$ ) for $\mathrm{pH}$ values of 4, 7, and 10, respectively (Figure 4). Our results are similar to those reported by Golub and Oren (1989) [39], who report that the reduction potential of $\mathrm{CrO}_{4}{ }^{2-}$ was $-0.6 \mathrm{~V}$ (using graphitic carbon electrodes), and by Welch et al. (2005) who report that the reduction potential of $\mathrm{HCrO}_{4}{ }^{-}$on glassy carbon was $-0.3 \mathrm{~V}$. The larger peak evident in our $\mathrm{CV}$ scans, which begins to emerge at $-1.1 \mathrm{~V}$, is likely associated with $\operatorname{Cr}(0)$ formation, a reaction used in electroplating processes[62]. The possible electrochemical reactions at the cathode and anode are [4,22]:

Cathode:
$2 H^{+}+2 e^{-} \rightarrow H_{2(g)}$
(5) $\mathrm{E}^{\mathrm{o}}=0 \mathrm{~V}$
$5 \mathrm{H}_{(a q)}^{+}+\mathrm{CrO}_{4}^{2-}{ }_{(a q)}^{2-}+3 e^{-} \rightarrow \mathrm{Cr}(\mathrm{OH})_{3(s)}+\mathrm{H}_{2} \mathrm{O}$
(6) $\mathrm{E}^{\mathrm{o}}=-0.13 \mathrm{~V}$
$\mathrm{Cr}_{(a q)}^{3+}+3 e^{-} \rightarrow \mathrm{Cr}_{(s)}$
(7) $\mathrm{E}^{\mathrm{o}}=-0.74 \mathrm{~V}$
$\mathrm{Cr}(\mathrm{OH})_{3(\mathrm{~s})}+e^{-} \rightarrow \mathrm{Cr}(\mathrm{OH})_{2}+\mathrm{OH}^{-}$
(8) $\mathrm{E}^{\mathrm{o}}=-1.1 \mathrm{~V}$
$\mathrm{Cr}(\mathrm{OH})_{2}+2 e^{-} \rightarrow \mathrm{Cr}+2 \mathrm{OH}^{-}$
(9) $\mathrm{E}^{\mathrm{o}}=-1.4 \mathrm{~V}$
$\mathrm{Cr}(\mathrm{OH})_{3}+3 e^{-} \rightarrow \mathrm{Cr}+3 \mathrm{OH}^{-}$
$\mathrm{Cr}_{(a q)}^{3+}+3 \mathrm{OH}_{(a q)}^{-} \rightarrow \mathrm{Cr}(\mathrm{OH})_{3(s)} \mathrm{K}_{s p}=7 \times 10^{-31}$
(10) $\mathrm{E}^{\mathrm{o}}=-1.34 \mathrm{~V}$
$2 \mathrm{Cr}(\mathrm{OH})_{3(s)} \rightarrow \mathrm{Cr}_{2} \mathrm{O}_{3}+3 \mathrm{H}_{2} \mathrm{O}$
Anode:
$2 \mathrm{H}_{2} \mathrm{O}-4 e^{-} \rightarrow \mathrm{O}_{2}+4 \mathrm{H}_{(a q)}^{+}$
(13) $\mathrm{E}^{\mathrm{o}}=1.23 \mathrm{~V}$ 


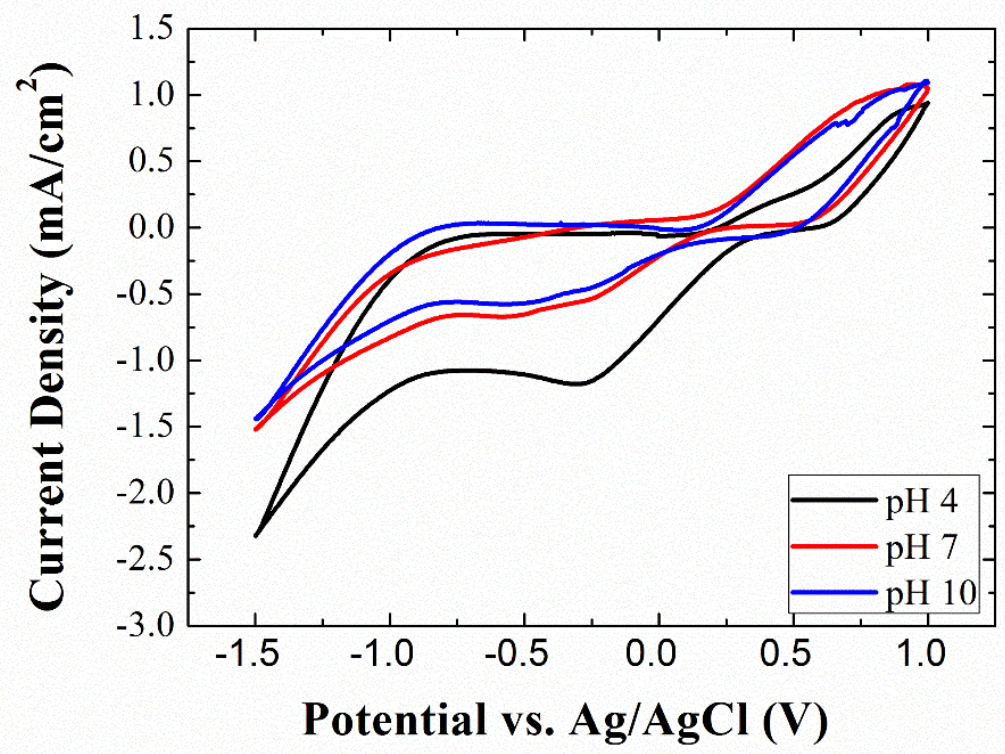

Figure 4: Background-subtracted $\mathrm{CV}$ curves at a sweep rate of $50 \mathrm{mV} / \mathrm{s}$ in $60 \mathrm{mM}$ of $\mathrm{Cr}(\mathrm{VI})$ solution. The background electrolyte solution was $0.5 \mathrm{M} \mathrm{Na}_{2} \mathrm{SO}_{4}$.

\subsection{Cr(VI) Removal by Electrically Conducting UF Membranes}

\subsubsection{Electrostatic repulsion}
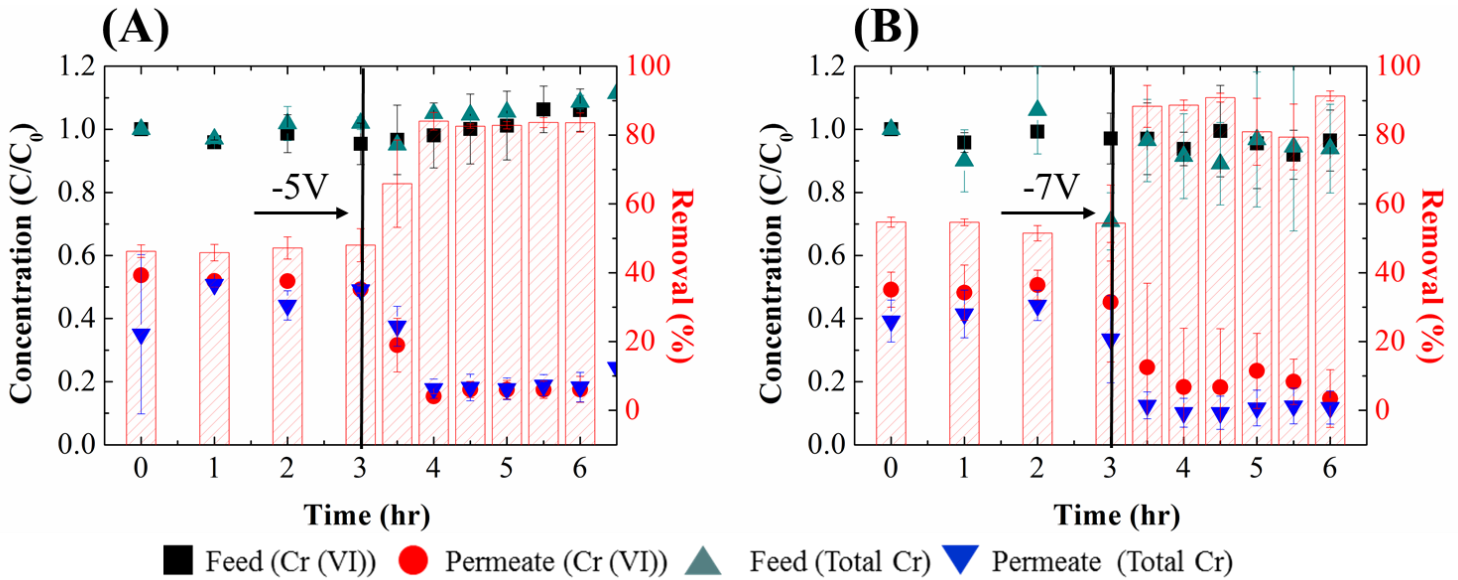

Figure 5: Removal of chromium from DI water spiked with 1 ppm $\mathrm{Cr}(\mathrm{VI})$ using a $2 \mu \mathrm{m}$-thick membrane. The red bar chart corresponds the \% of $\mathrm{Cr}(\mathrm{VI})$ removed by the membrane at each time point. (A) Normalized chromium concentrations as a function of time in feed and permeate of the membrane filtration system, when $5 \mathrm{~V}$ were applied to the membrane/counter electrode. (B) Normalized $\mathrm{Cr}(\mathrm{VI})$ concentrations as a function of time when $7 \mathrm{~V}$ were applied to the membrane/counter electrode.

To understand the role of electrostatic forces in $\mathrm{Cr}(\mathrm{VI})$ rejection by the UF membrane, different potentials were applied to the membrane surface while treating $\operatorname{Cr}(\mathrm{VI})$ solutions in DI 
water. In these experiments, because of the low $\mathrm{Cr}(\mathrm{VI})$ concentrations (1 ppm) and $\mathrm{pH}(6.5)$, the dominant species of $\mathrm{Cr}(\mathrm{VI})$ was $\mathrm{CrO}_{4}{ }^{2-}$ [8]. The non-polarized PVA-CNT membranes exhibited a 44\% removal rate of $\mathrm{Cr}(\mathrm{VI})$ (Figure 5A and $\mathrm{B}, 0-3$ hours); the removal rate of the uncoated PS35 UF support was $33.6 \%$ (Figure S4A). Based on published literature, polysulfone UF membranes are known to be negatively charged in the $\mathrm{pH}$ range of 4-10 [63]. Thus, the addition of the negatively charged CNT coating to the PS-35 material likely led to the small increase in $\mathrm{Cr}(\mathrm{VI})$ rejection over the uncoated membrane. These results are similar to those reported by others that demonstrated that UF membranes can remove toxic ions (chromate, arsenate, and perchlorate) to a modest degree $(42 \%)$, and attributed this removal to electrostatic repulsive forces between the negatively charged membranes and the metal anions [20]. Thus, it is likely that repulsive electrostatic forces are responsible for the observed rejection in the PVA-CNT UF membranes. When an electrical potential was applied to the membrane/counter electrode, $\mathrm{Cr}(\mathrm{VI})$ rejection increased significantly (Figure 5A, B, Figure S4A, B).

$\mathrm{Cr}(\mathrm{VI})$ rejection increased with increasing potentials, and the rejection increased immediately upon the application of the negative potential to the membrane surface (Figure 5A, B, Figure $\mathrm{S} 4 \mathrm{~B})$. At the highest cell potential tested $(7 \mathrm{~V}$, or $-1.01 \mathrm{~V}$ vs. $\mathrm{Ag} / \mathrm{AgCl}$ on the membrane, Figure $\mathrm{S} 5), \mathrm{Cr}(\mathrm{VI})$ removal reached $86.5 \%$. The removal efficiency of $\mathrm{Cr}(\mathrm{VI})$ over time at the other cell potentials $3 \mathrm{~V}(-0.37 \mathrm{~V}$ vs. $\mathrm{Ag} / \mathrm{AgCl}$ on the membrane; Figure S5) and $5 \mathrm{~V}(-0.7 \mathrm{~V}$ vs. $\mathrm{Ag} / \mathrm{AgCl}$ on the membrane; Figure S5)) was $64.4 \%$ and $83.4 \%$, respectively (Figure S4B, 5A). The Extended Nernst Plank model (Equation 4) was used to predict $\mathrm{CrO}_{4}{ }^{2-}$ rejection from electromigration (Figure S6). The model was moderately successful in predicting $\mathrm{CrO}_{4}{ }^{2-}$ rejection at the highest cell potential $(7 \mathrm{~V})$, but underestimated rejection at lower potentials (Figure S6). This underestimation could occur because the model does not consider changes to counter ion concentrations along the charged membrane surface in response to the surface potential, which could change the boundary conditions for the model.

Importantly, total chromium and $\mathrm{Cr}(\mathrm{VI})$ concentrations were statistically identical in both the feed and permeate, and both permeate and feed chromium concentrations did not change over time. These trends indicate that no chromium was reduced and removed from the feed solution during these experiments, likely because the solution electrical resistance was sufficiently high to prevent efficient electron transfer needed to drive electrochemical reactions, as manifested by the low current density: $0.02 \mathrm{~mA} / \mathrm{cm}^{2}$ at $5 \mathrm{~V}$ cell potential, and $0.17 \mathrm{~mA} / \mathrm{cm}^{2}$ at $7 \mathrm{~V}$ cell potential (Figure 6). While interesting, these results are of limited value in real-world conditions, where elevated electrolyte concentrations will lead to the collapse of the electrical double layer (EDL), which would severely limit the effectiveness of electrostatic repulsive forces [64]. 


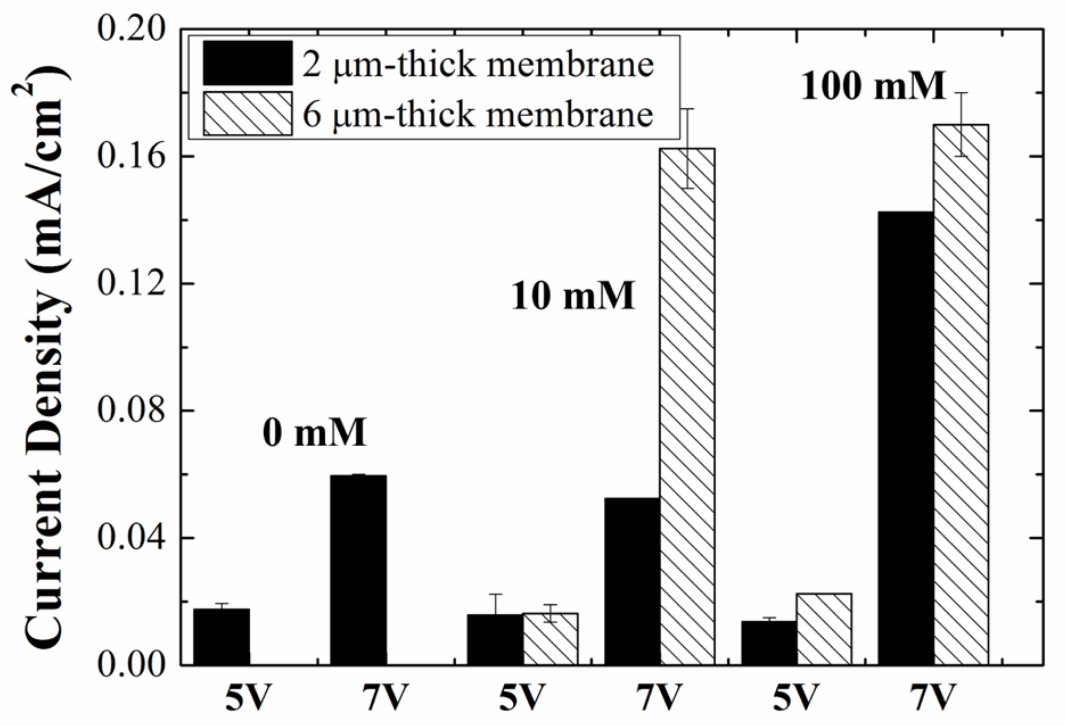

Figure 6: Current density as a function of the applied cell potentials ( 5 and $7 \mathrm{~V}$ ) and background electrolyte concentrations $\left(0,10,100 \mathrm{mM} \mathrm{Na}_{2} \mathrm{SO}_{4}\right)$ during experiments (with $1 \mathrm{ppm} \mathrm{Cr}(\mathrm{VI})$ ). The membrane area is $40 \mathrm{~cm}^{2}$. 


\subsection{2. $\quad$ Electrochemical reduction}
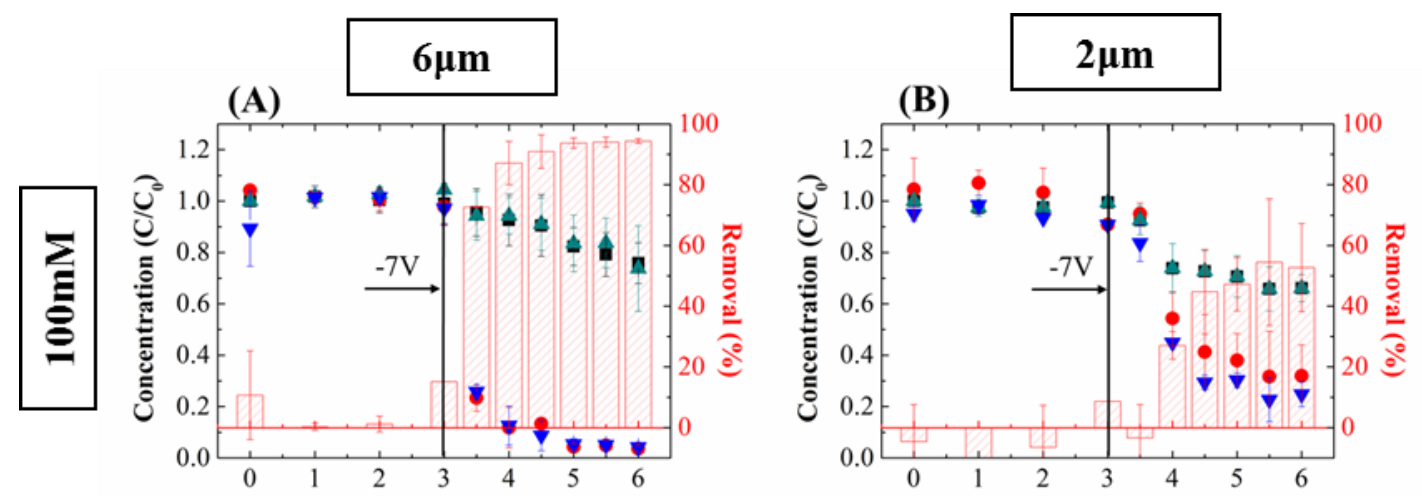

(C)

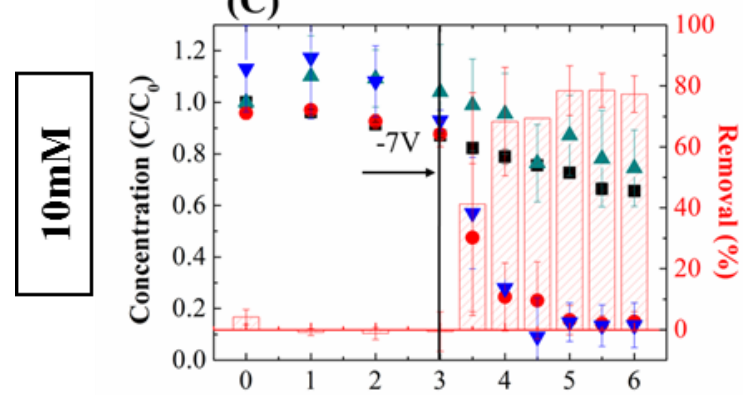

(D)

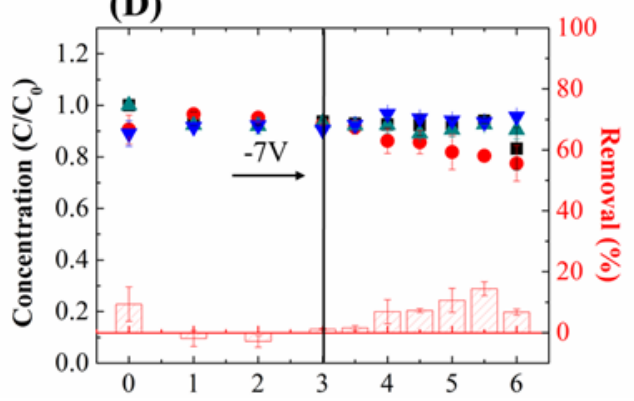

(E)

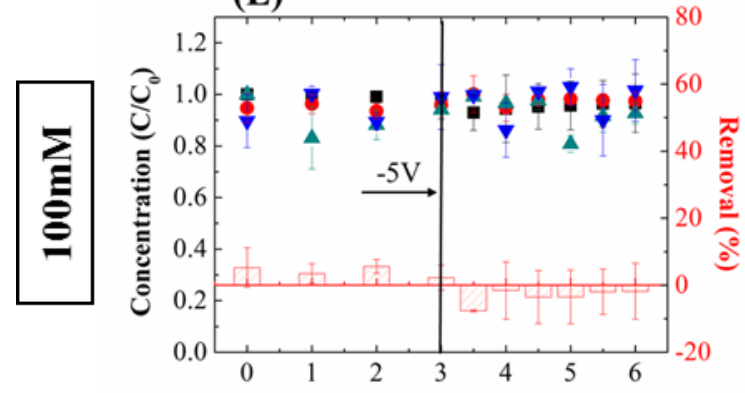

(F)

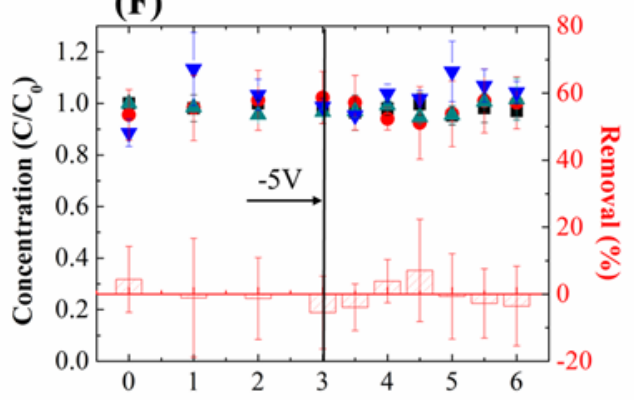

(G)

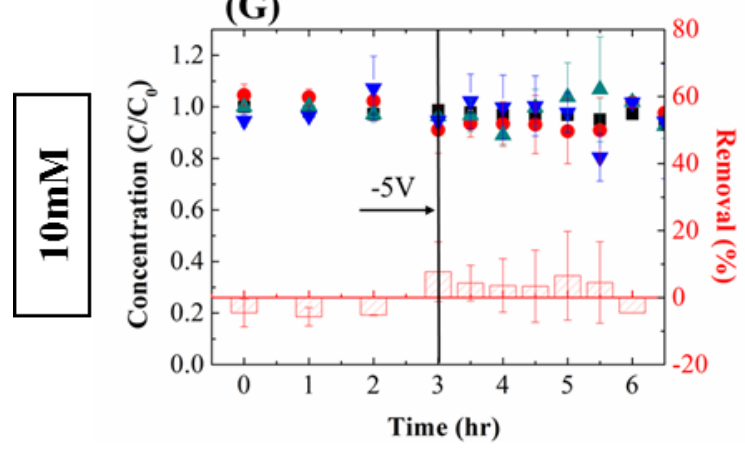

(H)

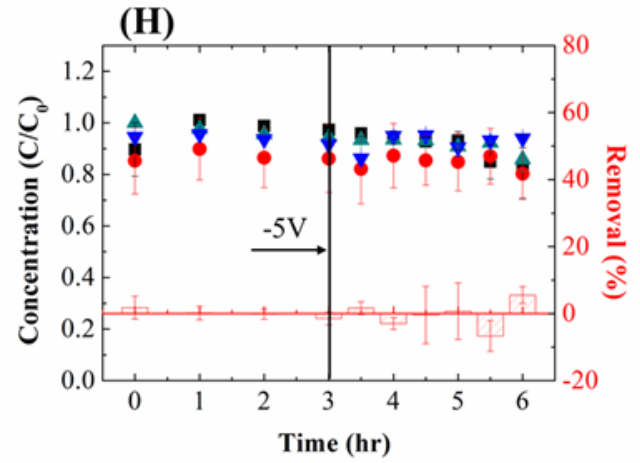

Feed (Cr (VI)) Permeate (Cr (VI))

Feed (Total $\mathrm{Cr}) \nabla$ Permeate (Total $\mathrm{Cr}$ )

Figure 7: Chromium concentrations ( $\mathrm{Cr}(\mathrm{VI})$ and total $\mathrm{Cr}$ ) in feed and permeate, and membrane removal (red bar chart) as a function of time, when different potentials were applied to membranes with two different thicknesses $(2 \mu \mathrm{m}$ and $6 \mu \mathrm{m})$ and electrolyte concentrations. In all experiments, $\mathrm{Cr}(\mathrm{VI})$ concentrations in the feed were $1 \mathrm{ppm}$. Specific experimental conditions 
were: (A) $7 \mathrm{~V}, 6 \mu \mathrm{m}$-thick membrane, $100 \mathrm{mM}$ of $\mathrm{Na}_{2} \mathrm{SO}_{4}$; (B) $7 \mathrm{~V}, 2 \mu \mathrm{m}$-thick membrane, 100 $\mathrm{mM}$ of $\mathrm{Na}_{2} \mathrm{SO}_{4}$; (C) $7 \mathrm{~V}, 6 \mu \mathrm{m}$-thick membrane, $10 \mathrm{mM}$ of $\mathrm{Na}_{2} \mathrm{SO}_{4}$; (D) $7 \mathrm{~V}, 2 \mu \mathrm{m}$-thick membrane, $10 \mathrm{mM}$ of $\mathrm{Na}_{2} \mathrm{SO}_{4}$; (E) $5 \mathrm{~V}, 6 \mu$-thick membrane, $100 \mathrm{mM}$ of $\mathrm{Na}_{2} \mathrm{SO}_{4}$; (F) $5 \mathrm{~V}, 2$ $\mu$ m-thick membrane, $100 \mathrm{mM}$ of $\mathrm{Na}_{2} \mathrm{SO}_{4}$; (G) $5 \mathrm{~V}, 6 \mu$ m-thick membrane, $10 \mathrm{mM}$ of $\mathrm{Na}_{2} \mathrm{SO}_{4} ;(\mathrm{H})$ $5 \mathrm{~V}, 2 \mu \mathrm{m}$-thick membrane, $10 \mathrm{mM}$ of $\mathrm{Na}_{2} \mathrm{SO}_{4}$.

To evaluate the impact of the background electrolyte on $\mathrm{Cr}(\mathrm{VI})$ removal, several experiments were carried out at different electrolyte concentrations, when $5 \mathrm{~V}$ and $7 \mathrm{~V}$ cell potentials were applied to the system using membranes of different thicknesses $(2 \mu \mathrm{m}$ and $6 \mu \mathrm{m})$ (Figure 7). When background electrolyte $\left(\mathrm{Na}_{2} \mathrm{SO}_{4}\right)$ concentrations were increased from $0 \mathrm{mM}$ (DI water) to $10 \mathrm{mM}$ and $100 \mathrm{mM}$, limited $\mathrm{Cr}$ (VI) removal was observed, regardless of the membrane thickness (Figure 7,0-3 hours). This was in contrast with the results in DI water, when $44 \%$ rejection of $\mathrm{Cr}(\mathrm{VI})$ was observed under identical operating conditions (Figure 5). The Extended Nernst Plank model (Equation 4) predicted that at higher ionic strengths, no rejection should occur from electromigration (Figure S7). This further confirmed the role of electrostatic repulsion in driving the rejection of $\mathrm{Cr}(\mathrm{VI})$ under very low ionic strength conditions, as the presence of background electrolytes (10 or $100 \mathrm{mM} \mathrm{Na}_{2} \mathrm{SO}_{4}$ ) is expected to compress the EDL and significantly reduce electrostatic forces (Figure S2).

The application of a sufficiently high cell potential had a dramatic impact on $\mathrm{Cr}(\mathrm{VI})$ removal; the magnitude of the electrical potential, the membrane thickness (i.e., the contact time with the membrane), and background electrolyte concentrations all affected the effectiveness of $\mathrm{Cr}(\mathrm{VI})$ removal (Figure 7). When $7 \mathrm{~V}$ cell potential were applied to the $6 \mu \mathrm{m}$ membranes $(-0.41$ $\mathrm{V}$ vs. $\mathrm{Ag} / \mathrm{AgCl}$ reference), $\mathrm{Cr}(\mathrm{VI})$ rejection was determined to be $94 \%$ and $78 \%$ for the $100 \mathrm{mM}$ and $10 \mathrm{mM} \mathrm{Na}_{2} \mathrm{SO}_{4}$ conditions, respectively (Figure 7A, C). In contrast, the $2 \mu \mathrm{m}$ membranes only achieved a removal rate of $53 \%$ and $11 \%$ for the $100 \mathrm{mM}$ and $10 \mathrm{mM} \mathrm{Na}_{2} \mathrm{SO}_{4}$ conditions, respectively (Figure $7 \mathrm{~B}, \mathrm{D}$ ). In the presence of $100 \mathrm{mM} \mathrm{Na}_{2} \mathrm{SO}_{4}$, the application of $5 \mathrm{~V}$ cell potential to the system resulted in no rejection. As the relative potential on the membrane $(-0.28$ $\mathrm{V}$ vs. $\mathrm{Ag} / \mathrm{Ag} / \mathrm{Cl})$ is lower than the $\mathrm{Cr}(\mathrm{VI})$ reduction potential $(-0.37 \mathrm{~V}$ vs. $\mathrm{Ag} / \mathrm{AgCl}$ at $\mathrm{pH} 7$ as determined by $\mathrm{CV}$, Figure 4), little $\mathrm{Cr}(\mathrm{VI})$ reduction will occur, and thus, little $\mathrm{Cr}(\mathrm{VI})$ removal will take place. In addition, the high ionic strength solution (100 $\left.\mathrm{mM} \mathrm{Na} \mathrm{SO}_{4}\right)$ prevents electrostatic repulsion from contributing towards $\mathrm{Cr}(\mathrm{VI})$ rejection. (Figure $7 \mathrm{E}$ and $\mathrm{F}$ ). However, when $5 \mathrm{~V}$ cell potential was applied to the system in the presence of $10 \mathrm{mM} \mathrm{Na} 2 \mathrm{SO}_{4}$, very limited $\mathrm{Cr}$ (VI) rejection was observed (5\% and $4.8 \%$ for the $2 \mu \mathrm{m}$ and $6 \mu \mathrm{m}$ membranes, respectively) (Figure $7 \mathrm{G}$ and $\mathrm{H}$ ). It is likely that this limited rejection is caused by electrostatic repulsion, which prevented $\mathrm{CrO}_{4}{ }^{2-}$ ions from entering the permeate. In all cases when $5 \mathrm{~V}$ cell potential were applied, the membrane thickness (and hence, membrane residence time) had very limited impact on performance (Figure $7 \mathrm{E}-\mathrm{H}$ ). Because the application of $5 \mathrm{~V}$ cell potential showed nearly no improvement over $0 \mathrm{~V}$, we did not test the impact of lower potentials. Critically, when $7 \mathrm{~V}$ cell potential were applied to the system, under certain conditions the concentration of total chromium and $\mathrm{Cr}(\mathrm{VI})$ dropped in the feed stream over time (Figure 7A, B, C). A mass balance on chromium and membrane autopsies revealed that the $\mathrm{Cr}(\mathrm{VI})$ from the feed stream was electrochemically reduced to $\mathrm{Cr}$ (III), which precipitated on the membrane surface and was removed from the system (see below for detailed analysis). As the feed stream was continuously recycled through the system, $\mathrm{Cr}(\mathrm{VI})$ reduction and precipitation as $\mathrm{Cr}$ (III) leads to the observed drop in $\mathrm{Cr}(\mathrm{VI})$ concentrations in the feed. No drop in flux was observed during these experiments, despite the formation of the precipitates, likely due to the very low concentrations 
of chromium in the water. The SEM image of post-experiment membrane (shown in Figure S8) also confirmed that there is no cake layer formation on the membrane surface.
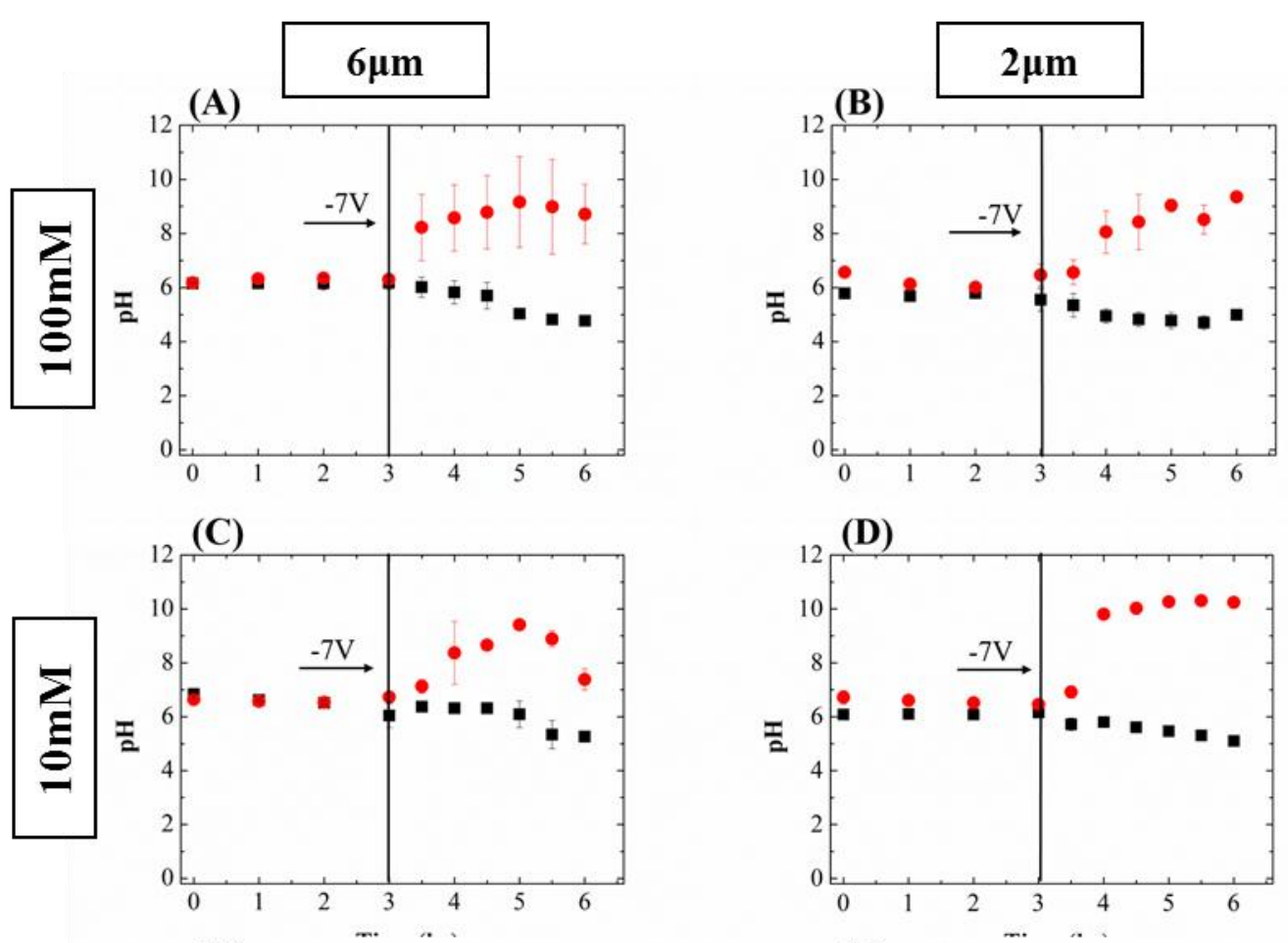

(E)
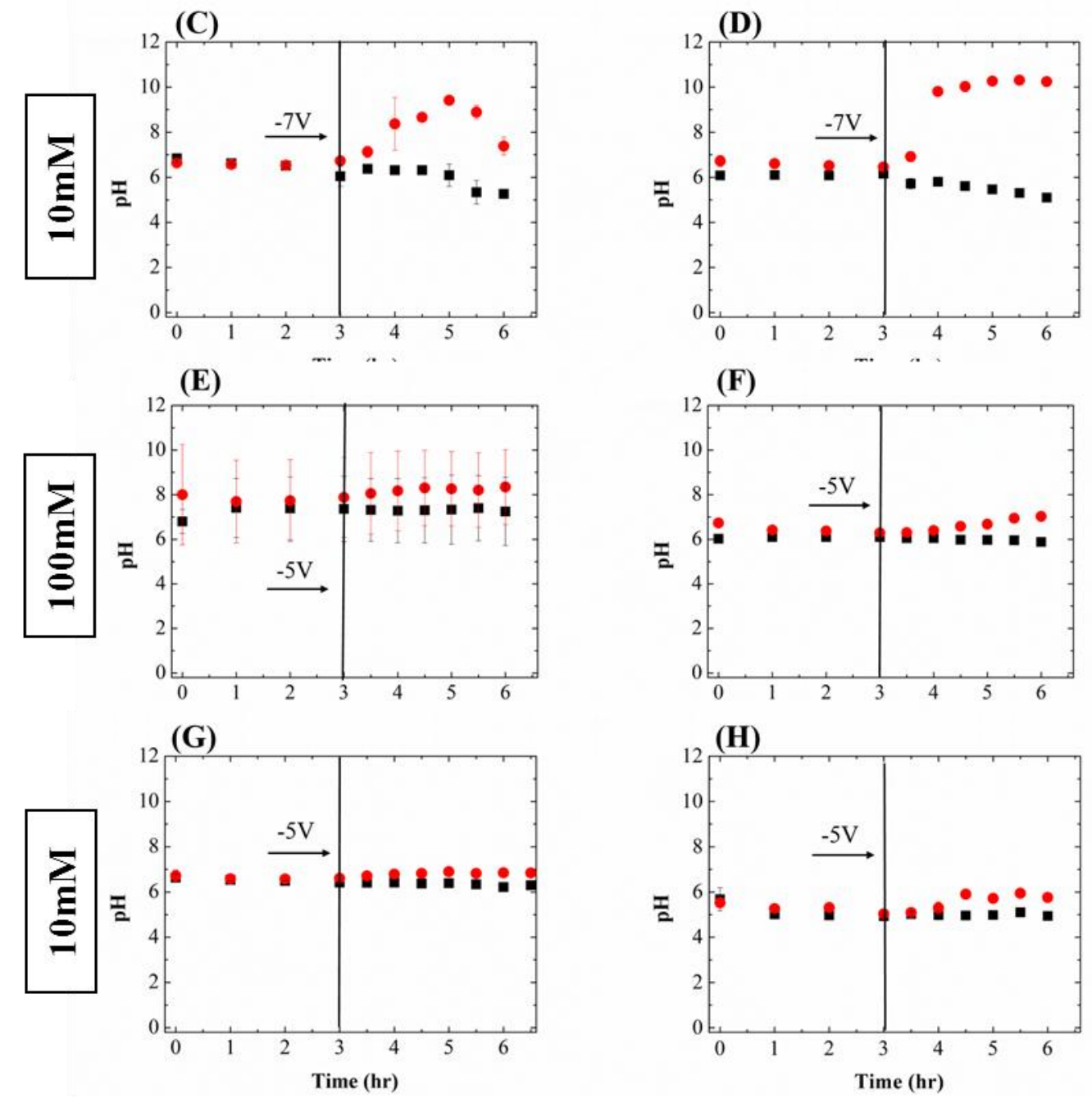

Feed

Figure 8: Changes in the $\mathrm{pH}$ of membrane permeate and retentate as a function of the applied cell potential, electrolyte concentrations, and membrane thickness. (A) $7 \mathrm{~V}, 6 \mu \mathrm{m}$-thick membrane, $100 \mathrm{mM} \mathrm{Na}_{2} \mathrm{SO}_{4}$ (B) 7V, $2 \mu$ m-thick membrane, $100 \mathrm{mM} \mathrm{Na} \mathrm{SO}_{4}$ (C) 7V, $6 \mu \mathrm{m}$ - 
thick membrane, $10 \mathrm{mM} \mathrm{Na}_{2} \mathrm{SO}_{4}$ (D) 7V, $2 \mu$ m-thick membrane, $10 \mathrm{mM} \mathrm{Na} \mathrm{SO}_{4}$ (E) $5 \mathrm{~V}, 6 \mu \mathrm{m}$ thick membrane, $100 \mathrm{mM} \mathrm{Na}_{2} \mathrm{SO}_{4}$ (F) 5V, $2 \mu \mathrm{m}$-thick membrane $100 \mathrm{mM} \mathrm{Na}_{2} \mathrm{SO}_{4}(\mathrm{G}) 5 \mathrm{~V}, 6 \mu \mathrm{m}$ thick membrane, $10 \mathrm{mM} \mathrm{Na}_{2} \mathrm{SO}_{4}(\mathrm{H}) 5 \mathrm{~V}, 2 \mu \mathrm{m}$-thick membrane $10 \mathrm{mM}, \mathrm{Na}_{2} \mathrm{SO}_{4}$

We hypothesize that the application of $7 \mathrm{~V}$ cell potential was sufficient to trigger electrochemical reduction of the soluble $\mathrm{Cr}(\mathrm{VI})$ species to insoluble $\mathrm{Cr}(\mathrm{III})$ solids $\left(\mathrm{Cr}_{2} \mathrm{O}_{3}\right.$ or $\left.\mathrm{Cr}(\mathrm{OH})_{3}\right)$, which precipitated on the membrane surface. In addition to $\mathrm{Cr}(\mathrm{VI})$ reduction, sufficiently high cathodic potentials will generate elevated hydroxide concentrations along the membrane surface. These elevated concentrations will facilitate the formation of insoluble $\mathrm{Cr}$ (III) solids, which can precipitate out on the membrane surface (Section 3.2, Eq. (1-5)). Measuring the $\mathrm{pH}$ of the permeate and retentate stream provided indirect evidence of hydroxide formation on the membrane surface (Figure 8). Upon application of $7 \mathrm{~V}$ cell potential, a rapid increase in permeate $\mathrm{pH}$ was measured (increasing to $\sim \mathrm{pH} 9$ ) while the $\mathrm{pH}$ of the retentate stream dropped to 5 (Figure 8 A-D). Inside the flow channel, the feed stream is in contact with the counter electrode (anode), which generates protons when a sufficiently high potential is applied. The generation of protons lowers the $\mathrm{pH}$ of the feed stream. The disproportionate increase in permeate $\mathrm{pH}$ is due to some hydroxides remaining in the feed, which raises the $\mathrm{pH}$ that stream. In contrast, since hydroxides are generated on the membrane, they disproportionally move into the permeate, raising the $\mathrm{pH}$ of that stream. Current densities measured when a $7 \mathrm{~V}$ cell potential was applied demonstrate that current densities increase with membrane thickness and elevated electrolyte concentrations (Figure 6). The application of $5 \mathrm{~V}$ cell potential did not lead to $\mathrm{Cr}(\mathrm{VI})$ electrochemical reduction, as evident by the poor rejection and lack of change in total chromium concentration in the feed stream (Figure $7 \mathrm{E}-\mathrm{H}$ ). While a $5 \mathrm{~V}$ cell potential was applied, the potential on the membrane surface vs. $\mathrm{Ag} / \mathrm{AgCl}$ was $-0.28 \mathrm{~V}$ (Figure 3). This potential is not sufficiently high to drive $\mathrm{Cr}(\mathrm{VI})$ electro-reduction, which required a potential of $-0.37 \mathrm{~V}$ vs. $\mathrm{Ag} / \mathrm{AgCl}$ at $\mathrm{pH} 7$ (Figure 4). This hypothesis is further strengthened by the current densities measured when $5 \mathrm{~V}$ cell potential were applied, which were approximately $0.02 \mathrm{~mA} / \mathrm{cm}^{2}$, regardless of the electrolyte concentration (Figure 6). Furthermore, at this voltage, the $\mathrm{pH}$ of the permeate was not elevated, which suggests that only limited water splitting occurred, which would limit $\mathrm{Cr}(\mathrm{OH})_{3}$ precipitate formation (Figure $8 \mathrm{E}-\mathrm{H}$ ).

Membrane thickness, and the resulting membrane residence time, played a key role in $\mathrm{Cr}(\mathrm{VI})$ removal. In all cases, the thicker membrane $(6 \mu \mathrm{m})$ exhibited superior performance better rejection and higher current densities (Figures 6 and 7). We attribute this increased performance to the longer times dissolved chromium species spent in contact with the electrically charged CNT network, which increased the probability of interaction and electron transfer. The presence of the thicker CNT layer did not significantly change the material's permeability, with $8 \mathrm{LMH}$ maintained at a pressure <1 psi. Similarly, the concentration of the background electrolyte had a large impact on $\mathrm{Cr}(\mathrm{VI})$ removal, with better $\mathrm{Cr}(\mathrm{VI})$ removal observed at higher electrolyte concentrations (Figure 7). We attribute this to the higher solution conductivity, which allows for more effective electron transfer between the membrane and $\mathrm{CrO}_{4}{ }^{2-}$ ions, leading to the reduction of this $\mathrm{Cr}(\mathrm{VI})$ species and formation of the insoluble $\mathrm{Cr}(\mathrm{OH})_{3}$. 


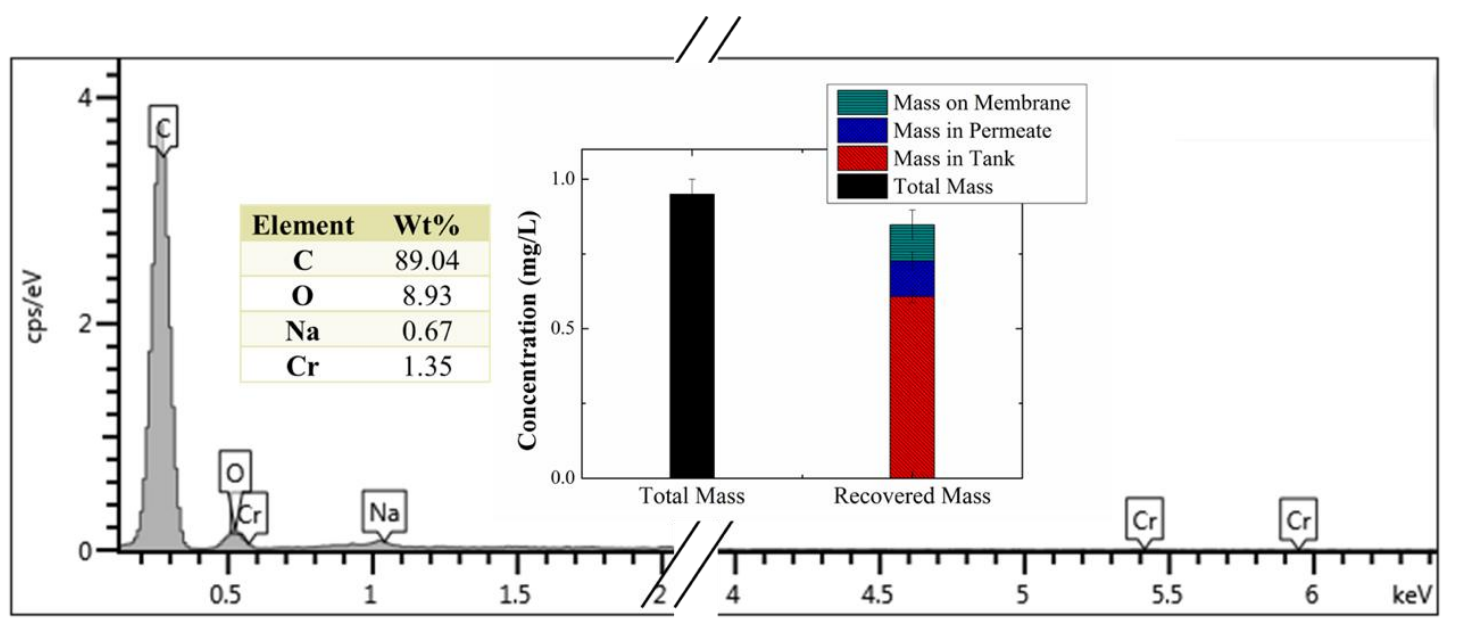

Figure 9: EDX spectrum of a used PVA-CNT membrane ( $6 \mu$ m-thick, $\left.7 \mathrm{~V}, 100 \mathrm{mM} \mathrm{Na} \mathrm{SO}_{4}\right)$; (Inset) Mass balance analysis of chromium in system.

To further investigate the formation of $\mathrm{Cr}(\mathrm{OH})_{3}$ on the PVA-CNT membrane surface, SEMEDX was performed on used PVA-CNT membranes (Figure 9). The SEM-EDX spectrum shows the presence of peaks from $\mathrm{C}, \mathrm{O}$ and $\mathrm{Cr}$ on the membrane with a $\mathrm{Cr}$ content of $1.35 \%$ (Figure 9). A mass balance on the chromium in the system demonstrated that $89 \%$ of chromium could be accounted for, with $13 \%$ deposited on the membrane, $13 \%$ in the permeate, and $63 \%$ remaining in the feed. It is unclear where the remaining $11 \%$ of chromium was located; one possibility is that some chromium precipitates were sloughed off the membrane surface and settled in the feed tank (Figure 9 inset). For this mass balance, chromium mass in the feed, permeate, and membrane precipitates were determined, by measuring total chromium in the feed and permeate, and digesting a membrane coupon with acid and measuring the resulting chromium concentration.

XPS analysis of a used membrane surface (post $7 \mathrm{~V}$ cell potential) was performed to examine the presence and speciation of $\mathrm{Cr}$ (III) solids. The spectrum of $\mathrm{Cr} 2 \mathrm{p}$ (Figure $10 \mathrm{~A}$ black line) includes the $\mathrm{Cr} 2 \mathrm{p}_{2 / 3}(578 \mathrm{eV})$ and $\mathrm{Cr} 2 \mathrm{p}_{1 / 2}(587 \mathrm{eV})$ envelopes. The $\mathrm{Cr} 2 \mathrm{p}_{2 / 3}$ envelope can be separated into two components, which are Cr (III) (Figure 10A red line) with a binding energy (B.E.) range (576.7 eV - 577.3 eV) [65] and $\mathrm{Cr}(\mathrm{VI})$ with a B.E. range around $~ 580 \mathrm{eV}$ (Figure $10 \mathrm{~A}$ green line). The primary peak shown at $576 \mathrm{eV}$ (Figure 10A) suggests that the dominant species present on the membrane was in the form of $\mathrm{Cr}$ (III). The $\mathrm{O} 1 \mathrm{~s}$ spectrum (Figure 10B) can be separated into three dominant peaks: the highest intensity peak $(530 \mathrm{eV})$ is assigned to hydroxyl, the peak at the lower B.E. is likely the result from $\mathrm{Cr}_{2} \mathrm{O}_{3}$, and the peak at the higher B.E. is assigned to water hydration. The primary intensity ratio of $\mathrm{O} / \mathrm{Cr}$ is 2.25 . Literature suggests that a ratio between $1.9-4.3$ indicates the presence of $\mathrm{Cr}(\mathrm{OH})_{3}$, while a ratio between 1.4-2.1 suggests the presence of $\mathrm{Cr}_{2} \mathrm{O}_{3}$ [65]. Thus, it is likely that the most common form of chromium on the membrane is $\mathrm{Cr}(\mathrm{OH})_{3}$. 
(A)

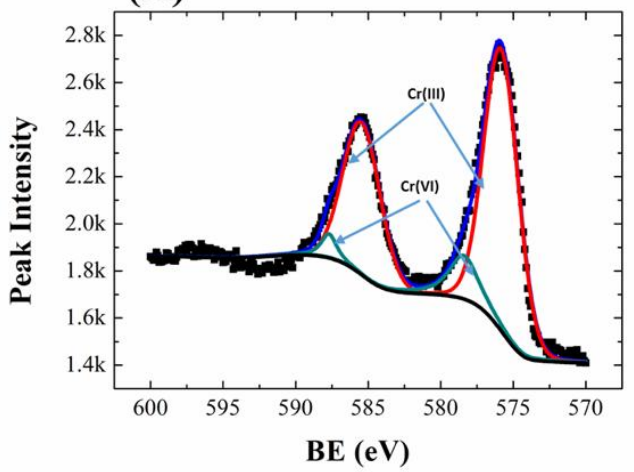

(B)

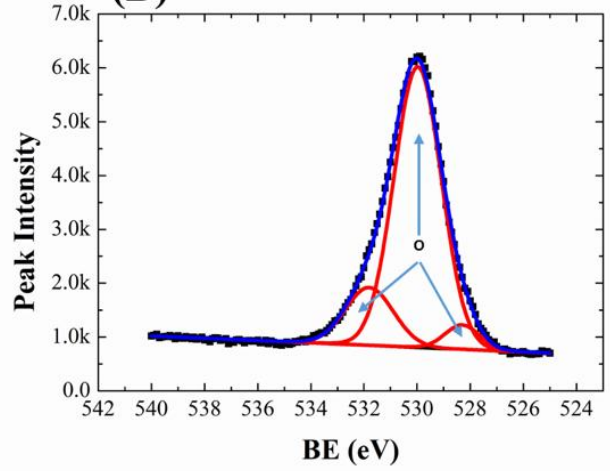

Figure 10: XPS analysis of used PVA-CNT membrane surface $(6 \mu \mathrm{m}$-thick, $7 \mathrm{~V}, 100 \mathrm{mM}$ $\mathrm{Na}_{2} \mathrm{SO}_{4}$ ): The black line represents the signal intensity of the XPS scan, and the blue line represents the best curve fit. (A) Chromium binding energy scan: red line and green lines are fitted curves for the $\mathrm{Cr}(\mathrm{III})$ and $\mathrm{Cr}(\mathrm{VI})$ data, respectively. (B) Oxygen binding energy scan: the red line represents the oxygen fitting curve.

\subsection{Cr(VI) Removal from tap water}

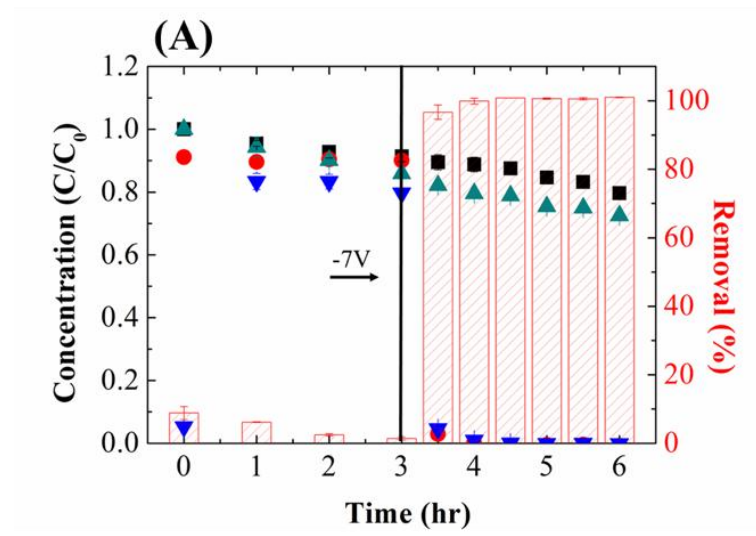

Feed (Cr (VI))

Permeate (Cr (VI)) Feed (Total Cr) Permeate (Total $\mathrm{Cr}$ )

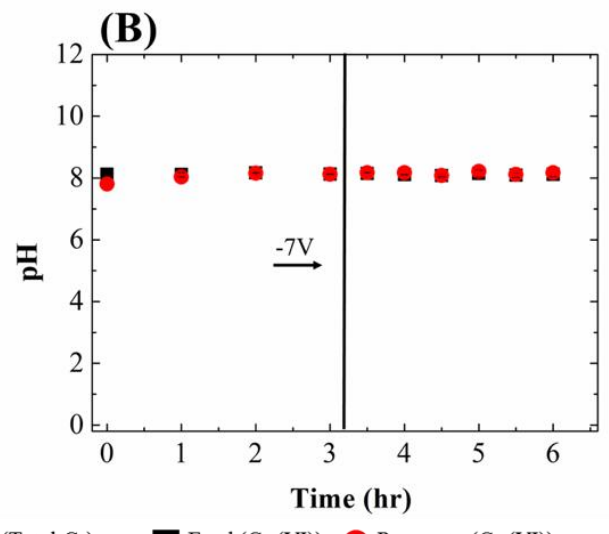

Feed (Cr (VI)) Permeate (Cr (VI))

Figure 11: Removal of chromium from tap water spiked with $1 \mathrm{ppm} \mathrm{Cr}(\mathrm{VI})$ using a $6 \mu \mathrm{m}$-thick membrane. (A) Chromium concentrations and $\mathrm{Cr}(\mathrm{VI})$ removal, when a PVA-CNT membrane (6 $\mu \mathrm{m}$-thick, $7 \mathrm{~V}$ ) was used to treat $\mathrm{Cr}(\mathrm{VI})$-spiked tap water. The black line indicates when the potential was applied to the membrane surface. (B) $\mathrm{pH}$ changes as a function of experimental time in the feed and permeate.

To assess the ability of PVA-CNT UF membranes to remove $\mathrm{Cr}(\mathrm{VI})$ from natural water, experiments were performed using the optimal operational conditions identified in the simplified water matrices $-\mathrm{a}$ cell potential of $7 \mathrm{~V}(-0.38 \mathrm{~V}$ vs. $\mathrm{Ag} / \mathrm{AgCl}$ in tap water) and a $6 \mu \mathrm{m}$-thick PVA-CNT membrane. In these experiments, the membrane was used to treat $\mathrm{Cr}(\mathrm{VI})$ spiked City of Riverside tap water. When the cell potential was applied, permeate $\mathrm{Cr}(\mathrm{VI})$ concentrations dramatically decreased, with overall $\mathrm{Cr}(\mathrm{VI})$ removal exceeding 99\% (Figure $11 \mathrm{~A})$. Incidentally, this removal rate is higher than the $\mathrm{Cr}(\mathrm{VI})$ removal measured in the simplified aqueous matrix $\left(\mathrm{Na}_{2} \mathrm{SO}_{4}\right.$ only; Figure $\left.7 \mathrm{~A}\right)$. In these experiments, both $\mathrm{Cr}(\mathrm{VI})$ and total chromium concentrations in the feed declined once the potential was applied to the membrane, suggesting that $\mathrm{Cr}(\mathrm{VI})$ was electrochemically reduced and subsequently precipitated on the membrane. However, the $\mathrm{pH}$ of both feed and permeate did not change upon the application of the potential (Figure 11B). We 
speculate that the natural buffering capacity (due to carbonate in the water) of the tap water is responsible for the attenuated $\mathrm{pH}$ response. City of Riverside tap water is produced from groundwater aquifers, and contains 49 ppm calcium, $12 \mathrm{ppm}$ magnesium, $121 \mathrm{ppm}$ sodium, and $208 \mathrm{ppm}\left(\right.$ as $\mathrm{CaCO}_{3}$ ) hardness [66]. EDX analysis of the membrane surface revealed the presence of large amounts of calcium and magnesium precipitates, likely in the form of $\mathrm{Ca}(\mathrm{OH})_{2}$ and $\mathrm{Mg}(\mathrm{OH})_{2}$ (Figure S9). Thus, some hydroxide ions generated on the membrane surface could be consumed by this precipitation reaction. Due to the overwhelming concentrations of calcium and magnesium, EDX peaks associated with chromium could not be resolved. However, we believe $\mathrm{Cr}(\mathrm{OH})_{3}$ precipitates were formed on the membrane surface since both $\mathrm{Cr}(\mathrm{VI})$ and total chromium concentrations declined upon the application of the potential (Figure 11A). Interestingly, the application of a potential to the membrane surface led to the removal of other metal anions from the tap water (Table S2), including strontium (77.8\% removal) and uranium (58.8\% removal); a detailed investigation regarding the mechanism responsible for the observed removal is beyond the scope of this study. In addition, it is important to note that during the short experimental period of this study ( 3 hours with voltage applied), no drop in flux was observed. However, it is very possible that over long periods of time, mineral scaling could lead to membrane fouling and flux decline. Considering the very low concentrations of $\mathrm{Cr}(\mathrm{VI})$ in most water resources, the main fouling species will likely be $\mathrm{Ca}(\mathrm{OH})_{2}$ and $\mathrm{Mg}(\mathrm{OH})_{2}$. While certainly important for the long-term evaluation of this technology, the impact of this phenomenon will be investigated in a later study. Another important consideration is membrane regeneration. $\mathrm{Cr}$ (III) and other metal hydroxides and carbonate scale can be removed from the membrane surface by exposing the membrane to a small volume of acid solution [67]. Importantly, the dissolution of $\mathrm{Cr}$ (III) precipitates with acid does not lead to chromium oxidation. Thus, the acid rinse water would not contain Cr(VI), and could be easily disposed of. For example, dissolved $\mathrm{Cr}$ (III) could be re-precipitated in bulk form by adding lime or caustic soda; $\mathrm{Cr}$ (III) solids can be disposed of in landfills [68].

\subsection{Economic Analysis}

The additional energy required to electrochemically reduce $\mathrm{Cr}(\mathrm{VI})$ and split water was determined to be $1.48 \mathrm{kWhr} / \mathrm{m}^{3}$ of permeate, which, when using California commercial electricity rates $(\$ 0.134 / \mathrm{kWhr}$ for 2016$)$ translates to an additional cost of $\$ 0.14 / \mathrm{m}^{3}$ of treated water. This additional energy was calculated based on the current density and potential applied to the membrane surface. This cost is highly sensitive to the membrane flux; if membrane flux was doubled (to $16 \mathrm{LMH}$, with a corresponding doubling of CNT thickness that maintains an equivalent membrane residence time), the cost would halve $\left(\$ 0.07 / \mathrm{m}^{3}\right)$. This is not an unreasonable flux for UF systems, and thus, it is reasonable to expect that energy-related costs could be significantly reduced. Standard UF drinking water treatment processes are relatively inexpensive to operate, with total (capital and operations and maintenance) costs estimated to be $\$ 0.28 / \mathrm{m}^{3}$ for a $20,000 \mathrm{~m}^{3} /$ day plant [69]. Thus, the total cost of the $\mathrm{Cr}(\mathrm{VI})$ treatment using electrically conducting UF membranes would be $\$ 0.42 / \mathrm{m}^{3}$. The total cost associated with existing $\mathrm{Cr}(\mathrm{VI})$ removal practices are $\$ 0.29 / \mathrm{m}^{3}$ and $\$ 0.38 / \mathrm{m}^{3}$ for ion exchange and reduction/coagulation, respectively [70].

\section{Conclusion}

This work has successfully demonstrated that the application of a negative potential to the surface of an electrically conducting UF membrane can electrochemically remove $\mathrm{Cr}(\mathrm{VI})$. The 
mechanism responsible for the observed $\mathrm{Cr}(\mathrm{VI})$ removal depends on the background ionic strength of the feed solution. Under low ionic strength conditions, electrostatic repulsive forces between the negatively charged membrane and $\mathrm{CrO}_{4}^{-2}$. If sufficient electrolyte is present, soluble $\mathrm{Cr}(\mathrm{VI})$ species are reduced to insoluble $\mathrm{Cr}(\mathrm{III})$, which precipitate on the membrane surface, primarily as $\mathrm{Cr}(\mathrm{OH})_{3}$, and are removed from the treated water stream. When these electrically conducting PVA-CNT UF membranes were used to treat tap water spiked with $\mathrm{Cr}(\mathrm{VI})$, removal exceeded 99\% when $7 \mathrm{~V}$ were applied to the membrane/counter electrode. In addition to water chemistry, it was found that the membrane contact time had a significant impact on $\mathrm{Cr}(\mathrm{VI})$ removal, with thicker membranes demonstrating more effective removal. While the costs of the membrane system are greater than those associated with the reduction/coagulation and ion exchange processes, it is important to note that the reduction/coagulation process is nearly impossible to implement on a small scale, and generates large volumes of hazardous waste. Furthermore, drinking water treated for $\mathrm{Cr}(\mathrm{VI})$ contamination using either ion exchange or reduction/coagulation would likely require additional treatment before it could be used, increasing these costs further. Thus, electrically conducting UF membranes offer a scalable and cost-effective alternative to traditional $\mathrm{Cr}(\mathrm{VI})$ removal steps, increasing the availability of clean drinking water and improving human health.

\section{Acknowledgment}

We appreciate the funding from the ACS Petroleum Research Fund (54649-dni9), the Office of Naval Research (n00014-14-1-0809), and the National Science Foundation (1553756, DMR0958796). 


\section{References}

[1] S. Velazquez-Peña, C. Barrera-Díaz, I. Linares-Hernández, B. Bilyeu, S. a. MartínezDelgadillo, An effective electrochemical Cr(VI) removal contained in electroplating industry wastewater and the chemical characterization of the sludge produced, Ind. Eng. Chem. Res. 51 (2012) 5905-5910. doi:10.1021/ie200968s.

[2] C.G. Daughton, Non-regulated water contaminants: Emerging research, Environ. Impact Assess. Rev. 24 (2004) 711-732. doi:10.1016/j.eiar.2004.06.003.

[3] M. Costa, Toxicity and Carcinogenicity of $\mathrm{Cr}(\mathrm{VI})$ in Animal Models and Humans, Crit. Rev. Toxicol. 27 (1997) 431-442. doi:10.3109/10408449709078442.

[4] W. Jin, H. Du, S. Zheng, Y. Zhang, Electrochemical processes for the environmental remediation of toxic Cr ( VI ): A review, Electrochim. Acta. 191 (2016) 1044-1055. doi:10.1016/j.electacta.2016.01.130.

[5] M. Chebeir, H. Liu, Kinetics and Mechanisms of Cr(VI) Formation via the Oxidation of Cr(III) Solid Phases by Chlorine in Drinking Water, Environ. Sci. Technol. 50 (2016) 701-710. doi:10.1021/acs.est.5b05739.

[6] M. Chebeir, G. Chen, H. Liu, Emerging investigators series: frontier review: occurrence and speciation of chromium in drinking water distribution systems, Environ. Sci. Water Res. Technol. (2016). doi:10.1039/C6EW00214E.

[7] J. Guertin, J.A. Jacobs, C.P. Avakian, Chromium (VI) handbook, CRC Press, 2004.

[8] R. Rakhunde, L. Deshpande, H.D. Juneja, Chemical Speciation of Chromium in Water: A Review, Crit. Rev. Environ. Sci. Technol. 42 (2012) 776-810. doi:10.1080/10643389.2010.534029.

[9] C.M. Welch, O. Nekrassova, R.G. Compton, Reduction of hexavalent chromium at solid electrodes in acidic media: Reaction mechanism and analytical applications, Talanta. 65 (2005) 74-80. doi:10.1016/j.talanta.2004.05.017.

[10] US EPA, Drinking Water Regulatory Information, (n.d.). https://www.epa.gov/dwreginfo/drinking-water-regulatory-information\#chemcont.

[11] California Department of Public Healt, DPH-11-005 Hexavalent Chromium MCL, 2014.

[12] E. Brockovich, D. Andrews, B. Walker, N. Carolina, CARCINOGEN IN TAP WATER OF MORE THAN AMERICANS, (2016) 1-13.

[13] S.W.R.C.B. California Environmental Protection Agency, Chromium-6 Drinking Water MCL, (n.d.). http://www.waterboards.ca.gov/drinking_water/certlic/drinkingwater/Chromium6.shtml.

[14] R. Espinosa, M. Quir, The removal of Cr(VI) from dilute aqueous solution of activated carbon, 279 (1992) 92-97.

[15] K. Pillay, E.M. Cukrowska, N.J. Coville, Multi-walled carbon nanotubes as adsorbents for the removal of parts per billion levels of hexavalent chromium from aqueous solution, $\mathrm{J}$. Hazard. Mater. 166 (2009) 1067-1075. doi:10.1016/j.jhazmat.2008.12.011.

[16] S. Rengaraj, K.-H. Yeon, S.-H. Moon, Removal of chromium from water and wastewater by ion exchange resins, J. Hazard. Mater. 87 (2001) 273-287. doi:10.1016/S03043894(01)00291-6.

[17] R. Dong, J. Zhang, B. Zhou, J. Zhou, Application of a novel quaternized ammonium poly(vinyl alcohol)-based hybrid anion exchange membrane for the removal of $\mathrm{Cr}(\mathrm{VI})$ from wastewater, Water Sci. Technol. 70 (2014) 1602-1609. doi:10.2166/wst.2014.403.

[18] Y. Xing, X. Chen, D. Wang, Electrically Regenerated Ion Exchange for Removal and Recovery of Cr ( VI ) from Wastewater, 41 (2007) 1439-1443. 
[19] A. Hafiane, D. Lemordant, M. Dhahbi, Removal of Hexavalent Chromium by nanofiltration, Desalination. 130 (2000) 305-312.

[20] J. Yoon, G. Amy, J. Chung, J. Sohn, Y. Yoon, Removal of toxic ions (chromate, arsenate, and perchlorate) using reverse osmosis, nanofiltration, and ultrafiltration membranes, Chemosphere. 77 (2009) 228-235. doi:10.1016/j.chemosphere.2009.07.028.

[21] Y. Huang, S. Koseoglu, Separation of heavy metals from industrial waste streams by membrane separation technology, Waste Manag. 13 (1993) 481-501.

doi:http://dx.doi.org/10.1016/0956-053X(93)90079-C.

[22] C.E. Barrera-Díaz, V. Lugo-lugo, B. Bilyeu, A review of chemical, electrochemical and biological methods for aqueous Cr ( VI ) reduction, J. Hazard. Mater. 223-224 (2012) 112. doi:10.1016/j.jhazmat.2012.04.054.

[23] Y. Ku, I. Jung, Photocatalytic reduction of $\mathrm{Cr}$ (VI) in aqueous solutions by UV irradiation with the presence of titanium dioxide, Water Res. 35 (2001) 135-142.

http://www.sciencedirect.com/science/article/pii/S0043135400000981.

[24] R. Mu, Z. Xu, L. Li, Y. Shao, H. Wan, S. Zheng, On the photocatalytic properties of elongated $\mathrm{TiO} 2$ nanoparticles for phenol degradation and $\mathrm{Cr}(\mathrm{VI})$ reduction, J. Hazard. Mater. 176 (2010) 495-502. doi:10.1016/j.jhazmat.2009.11.057.

[25] A.J. Chaudhary, N.C. Goswami, S.M. Grimes, Electrolytic removal of hexavalent chromium from aqueous solutions, J. Chem. Technol. Biotechnol. 78 (2003) 877-883. doi:10.1002/jctb.871.

[26] P. Lakshmipathiraj, G. Bhaskar Raju, M. Raviatul Basariya, S. Parvathy, S. Prabhakar, Removal of Cr (VI) by electrochemical reduction, Sep. Purif. Technol. 60 (2008) 96-102. doi:10.1016/j.seppur.2007.07.053.

[27] C.E. Barrera-Díaz, V. Lugo-Lugo, B. Bilyeu, A review of chemical, electrochemical and biological methods for aqueous Cr(VI) reduction, J. Hazard. Mater. 223-224 (2012) 1-12. doi:10.1016/j.jhazmat.2012.04.054.

[28] G. Qin, M.J. McGuire, N.K. Blute, C. Seidel, L. Fong, Hexavalent chromium removal by reduction with ferrous sulfate, coagulation, and filtration: A pilot-scale study, Environ. Sci. Technol. 39 (2005) 6321-6327. doi:10.1021/es050486p.

[29] L. Alvarado, I.R. Torres, A. Chen, Integration of ion exchange and electrodeionization as a new approach for the continuous treatment of hexavalent chromium wastewater, Sep. Purif. Technol. 105 (2013) 55-62. doi:10.1016/j.seppur.2012.12.007.

[30] M. Muthukrishnan, B.K. Guha, Effect of $\mathrm{pH}$ on rejection of hexavalent chromium by nanofiltration, Desalination. 219 (2008) 171-178. doi:10.1016/j.desal.2007.04.054.

[31] J.R. Werber, C.O. Osuji, M. Elimelech, Materials for next-generation desalination and water purification membranes, Nat. Rev. Mater. 1 (2016) 16018. http://dx.doi.org/10.1038/natrevmats.2016.18.

[32] G. Pugazhenthi, S. Sachan, N. Kishore, A. Kumar, Separation of chromium (VI) using modified ultrafiltration charged carbon membrane and its mathematical modeling, J. Memb. Sci. 254 (2005) 229-239. doi:10.1016/j.memsci.2005.01.011.

[33] Z. Yao, Y. Li, Y. Cui, K. Zheng, B. Zhu, H. Xu, L. Zhu, Tertiary amine block copolymer containing ultrafiltration membrane with $\mathrm{pH}$-dependent macromolecule sieving and $\mathrm{Cr}(\mathrm{VI})$ removal properties, Desalination. 355 (2015) 91-98. doi:10.1016/j.desal.2014.10.030.

[34] L. Gzara, M. Dhahbi, Removal of chromate anions by micellar-enhanced ultrafiltration using cationic surfactants, Desalination. 137 (2001) 241-250. doi:10.1016/S00119164(01)00225-9. 
[35] G. Chen, Electrochemical technologies in wastewater treatment, Sep. Purif. Technol. 38 (2004) 11-41. doi:10.1016/j.seppur.2003.10.006.

[36] G. Almaguer-Busso, G. Velasco-Martínez, G. Carreño-Aguilera, S. Gutiérrez-Granados, E. Torres-Reyes, A. Alatorre-Ordaz, A comparative study of global hexavalent chromium removal by chemical and electrochemical processes, Electrochem. Commun. 11 (2009) 1097-1100. doi:10.1016/j.elecom.2009.03.012.

[37] S.B. Faldini, S.M.L. Agostinho, H.C. Chagas, The effect of chloride ions on the electrochemical reduction of $\mathrm{Cr}(\mathrm{VI})$ to $\mathrm{Cr}(\mathrm{III})$ at a rotating disk electrode, J. Electroanal. Chem. 284 (1990) 173-183. doi:10.1016/0022-0728(90)87070-Z.

[38] L.D. Burke, P.F. Nugent, Dichromate reduction on gold and platinum electrodes in aqueous acid solutions, Electrochim. Acta. 42 (1997) 399-411. doi:10.1016/S00134686(96)00234-4.

[39] D. Golub, Y. Oren, Removal of chromium from aqueous solutions by treatment with porous carbon electrodes: Electrochemical principles, J. Appl. Electrochem. 19 (1989) 311-316. doi:10.1007/BF01015228.

[40] E.P.L. Roberts, H. Yu, Chromium removal using a porous carbon felt cathode, J. Appl. Electrochem. 32 (2002) 1091-1099. doi:10.1023/A:1021282015050.

[41] W. Duan, A. Ronen, S.L. Walker, D. Jassby, Polyaniline-Coated Carbon Nanotube Ultrafiltration Membranes: Enhanced Anodic Stability for In Situ Cleaning and ElectroOxidation Processes, ACS Appl. Mater. Interfaces. 0 (n.d.) null.

doi:10.1021/acsami.6b07196.

[42] H. Liu, C.D. Vecitis, Reactive transport mechanism for organic oxidation during electrochemical filtration: Mass-transfer, physical adsorption, and electron-transfer, J. Phys. Chem. C. 116 (2012) 374-383. doi:10.1021/jp209390b.

[43] A. V. Dudchenko, J. Rolf, K. Russell, W. Duan, D. Jassby, Organic fouling inhibition on electrically conducting carbon nanotube-polyvinyl alcohol composite ultrafiltration membranes, J. Memb. Sci. 468 (2014) 1-10. doi:10.1016/j.memsci.2014.05.041.

[44] W. Duan, A. Dudchenko, E. Mende, C. Flyer, X. Zhu, D. Jassby, Electrochemical mineral scale prevention and removal on electrically conducting carbon nanotube--polyamide reverse osmosis membranes, Environ. Sci. Process. Impacts. 16 (2014) 1300-1308.

[45] W. Duan, A. Ronen, J.V. de Leon, A. Dudchenko, S. Yao, J. Corbala-Delgado, A. Yan, M. Matsumoto, D. Jassby, Treating anaerobic sequencing batch reactor effluent with electrically conducting ultrafiltration and nanofiltration membranes for fouling control, J. Memb. Sci. 504 (2016) 104-112. doi:10.1016/j.memsci.2016.01.011.

[46] A. Ronen, W. Duan, I. Wheeldon, S.L. Walker, D. Jassby, Microbial attachment inhibition through low voltage electrochemical reactions on electrically conducting membranes., Environ. Sci. Technol. (2015). doi:10.1021/acs.est.5b01281.

[47] L. Guo, Y. Jing, B.P. Chaplin, Development and Characterization of Ultrafiltration TiO2 Magneli Phase Reactive Electrochemical Membranes, Environ. Sci. Technol. 50 (2016) 1428-1436. doi:10.1021/acs.est.5b04366.

[48] A.M. Zaky, B.P. Chaplin, Porous substoichiometric $\mathrm{TiO} 2$ anodes as reactive electrochemical membranes for water treatment., Environ. Sci. Technol. 47 (2013) 655463. doi:10.1021/es401287e.

[49] G. Gao, Q. Zhang, Z. Hao, C.D. Vecitis, Carbon Nanotube Membrane Stack for Flowthrough Sequential Regenerative Electro-Fenton Carbon Nanotube Membrane Stack for Flow-through Sequential Regenerative Electro-Fenton, Environ. Sci. Technol. (2015). 
doi:10.1021/es505679e.

[50] C.D. Vecitis, K.R. Zodrow, S. Kang, M. Elimelech, Electronic-structure-dependent bacterial cytotoxicity of single-walled carbon nanotubes, ACS Nano. 4 (2010) 5471-5479. doi:10.1021/nn101558x.

[51] Guandao Gao, Q. Zhanga, C.D. Vecitis, CNT-PVDF composite flow-through electrode for single-pass sequential reduction-oxidation, J. Mater. Chem. A. 2 (2014) 6185-6190. doi:10.1039/c3ta14080f.

[52] A. Ronen, W. Duan, I. Wheeldon, S.L. Walker, D. Jassby, Low Voltage Electrochemical Microbial Attachment Inhibition on Electrically Conducting Surfaces, Environ. Sci. Technol. (2015). doi:10.1021/acs.est.5b01281.

[53] B.P. Chaplin, Critical review of electrochemical advanced oxidation processes for water treatment applications, Environ. Sci. Process. Impacts. 16 (2014) 1182-1203. doi:10.1039/C3EM00679D.

[54] G. Gao, C.D. Vecitis, Electrochemical carbon nanotube filter oxidative performance as a function of surface chemistry., Environ. Sci. Technol. 45 (2011) 9726-34. doi:10.1021/es202271z.

[55] C.-F. de Lannoy, D. Jassby, K. Gloe, A.D. Gordon, M.R. Wiesner, Aquatic biofouling prevention by electrically charged nanocomposite polymer thin film membranes., Environ. Sci. Technol. 47 (2013) 2760-8. doi:10.1021/es3045168.

[56] W. Chen, Z. Fan, L. Gu, X. Bao, C. Wang, Enhanced capacitance of manganese oxide via confinement inside carbon nanotubes., Chem. Commun. (Camb). 46 (2010) 3905-3907. doi:10.1039/c000517g.

[57] T. Tsuru, S. ichi Nakao, S. Kimura, Calculation of ion rejection by extended NernstPlanck equation with charged reverse osmosis membranes for single and mixed electrolyte solutions, J. Chem. Eng. Japan. 24 (1991) 511-517. doi:10.1252/jcej.24.511.

[58] N. Iadicicco, L. Paduano, V. Vitagliano, D. Chimica, F. Ii, V. Mezzocannone, Diffusion Coefficients for the System Potassium Chromate - Water at $25^{\circ} \mathrm{C}$, (1996) 529-533.

[59] E.W. Rice, L. Bridgewater, American Public Health Association., American Water Works Association., Water Environment Federation., Standard methods for the examination of water and wastewater., American Public Health Association, 2012.

[60] A. V. Dudchenko, J. Rolf, K. Russell, W. Duan, D. Jassby, Organic fouling inhibition on electrically conducting carbon nanotube - polyvinyl alcohol composite ultra filtration membranes, J. Memb. Sci. 468 (2014) 1-10. doi:10.1016/j.memsci.2014.05.041.

[61] C. Kuphasuk, Y. Oshida, C.J. Andres, S.T. Hovijitra, M.T. Barco, D.T. Brown, Electrochemical corrosion of titanium and titanium-based alloys, J. Prosthet. Dent. 85 (2001) 195-202. doi:10.1067/mpr.2001.113029.

[62] I. Donald, J. Barclay, B. Hants, W. Morris, C.F. Hants, ELECI‘RODEPOSITION OF CHROMIUM, 1977.

[63] D. Mockel, E. Staude, M. Dal-Cin, K. Darcovich, M. Guiver, Tangential flow streaming potential measurements: Hydrodynamic cell characterization and zeta potentials of carboxylated polysulfone membranes, J. Memb. Sci. 145 (1998) 211-222. doi:10.1016/S0376-7388(98)00077-5.

[64] M. Elimelech, J. Gregory, X. Jia, R.A. Williams, Particle Deposition and Aggregation Measurement, Modelling and Simulation, (n.d.).

[65] M.C. Biesinger, C. Brown, J.R. Mycroft, R.D. Davidson, N.S. McIntyre, X-ray photoelectron spectroscopy studies of chromium compounds, Surf. Interface Anal. 36 
(2004) 1550-1563. doi:10.1002/sia.1983.

[66] RIVERSIDE PUBLIC UTILITIES, Water Quality Report 2014, Riverside, 2014. http://www.riversideca.gov/utilities/pdf/wqar/2014-Water-Quality-Annual-Report.pdf.

[67] A. Antony, J.H. Low, S. Gray, A.E. Childress, P. Le-Clech, G. Leslie, Scale formation and control in high pressure membrane water treatment systems: A review, J. Memb. Sci. 383 (2011) 1-16. doi:10.1016/j.memsci.2011.08.054.

[68] S.B. Wilbur, Toxicological profile for chromium, US Department of Health and Human Services, Public Health Service, Agency for Toxic Substances and Disease Registry, 2000.

[69] Q.K. Tran, K.A. Schwabe, D. Jassby, Wastewater Reuse for Agriculture: Development of a Regional Water Reuse Decision-Support Model (RWRM) for Cost-Effective Irrigation Sources, Environ. Sci. Technol. (2016) acs.est.6b02073. doi:10.1021/acs.est.6b02073.

[70] M.J. McGuire, N.K. Blute, G. Qin, P. Kavounas, D. Froelich, L. Fong, Hexavalent Chromium Removal Using Anion Exchange and Reduction With Coagulation and Filtration, Water Res. Found. Proj. \#3167. (2007) 140. 

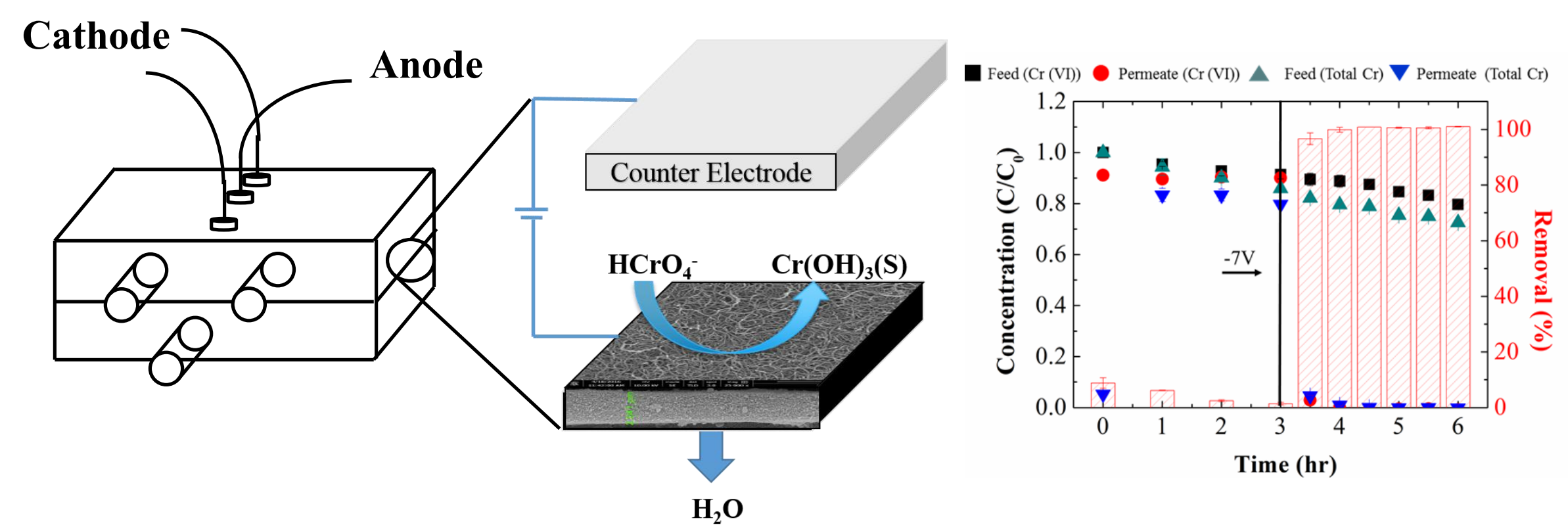